\title{
THE GENUS PERISSOCYTHERIDEA STEPHENSON, 1938 (CRUSTACEA: OSTRACODA) AND EVIDENCE OF BRACKISH WATER FACIES ALONG THE OLIGO-MIOCENE, PIRABAS FORMATION, EASTERN AMAZONIA, BRAZIL.
}

\author{
Anna Andressa Evangelista Nogueira ${ }^{\mathrm{a},}$, Maria Inês Feijó Ramos ${ }^{\mathrm{b}}$ \\ a Universidade Federal do Pará, Instituto de Geociências, Programa de Pós- \\ Graduação em Geologia e Geoquímica, Brazil \\ ${ }^{\mathrm{b}}$ Museu Paraense Emílio Goeldi, Campus de Pesquisa, Coordenação de Ciências da \\ Terra e Ecologia, Av. Perimetral, cx. postal 399, 1901, Belém, PA, Brazil
}

\section{ABSTRACT}

Perissocytheridea Stephenson is characteristic of brackish water facies. In 57 samples from the Upper Oligocene to Lower Miocene, from five localities, Pirabas Formation, Pará State, Brazil eleven species have been identified. Among these species, four are new reports: P. punctoreticulata n. sp., P. largulateralis n. sp., P. colini n. sp. and $P$. pirabensis n. sp.; five species in open nomenclature: Perissocytheridea sp. $1, P$. sp. 2, P. sp. 3, P. sp. 4, and P. sp. 5 and two species left in "aff." abbreviation: Perissocytheridea aff. P. pumila and Perissocytheridea aff. P. brachyforma subsp. excavata. The distributional pattern of the Perissocytheridea combined with the occurrence of foraminifera Elphidium and Ammonia in the studied sections supports the presence of the brackish water facies to the respective layers. Their quantitative variation through the studied sections indicate more than one phase of salinity reduction (about $>5$ and $<30 \mathrm{ppm}$ ) and/or the decrease of the sea level, forming lagoon along the Pirabas Formation. This genus has a wide paleobiogeographical occurrence and stratigraphic distribution ranging from the Cretaceous to Recent, and already been recorded in the northern of South America, especially in the Neogene of Solimões Basin, but this is the first report of a neotropical genus to the Oligo-Miocene deposits of Pirabas Formation, northern Brazilian Coast, Pará State.

Key words: brackish water Ostracods; Perissocytheridea; Pirabas Formation; OligoMiocene; Brazil. 


\section{Introduction}

The Oligo-Miocene Pirabas Formation represents a densely fossiliferous carbonate succession, discontinuously exposed along of the northern Coast of Brazil. This unit was discovered by Ferreira Penna (1876) and designated of "Pirabas" by Maury (1925) in the Fortaleza Island, considered the type locality. Based on paleontological and sedimentological data, the Pirabas Formation was interpreted as lagoon, mangrove, swamps and outer to restricted platform deposits (Ferreira 1977; Ferreira and Fernandes 1987; Góes et al. (1990), Rossetti and Góes (2004) and Rossetti 2006, Rossetti and Góes 2004).

Paleontological data is concentrated in the invertebrate macrofauna and subordinately in vertebrates and microfossil. Foraminifera and ostracod were described locally in outcrops and some core focusing mainly taxonomic studies (Petri 1952; 1954; 1957; Macedo 1971; Ferreira et al., 1978; Ferreira et al. 1981, 1984; Távora 1994a, 1994b, 1994c, Ramos et al. 2004), some authors focused in dating the Pirabas unit spite of the most these studies not presents a stratigraphic control more confident due to use of boreholes rather than drill cores (Petri 1957, Fernandes 1984; 1988; Fernandes and Távora 1990; Távora and Fernandes, 1999). In a more recent study of the ostracods from Pirabas Formation, a new biozonation is proposed corroborating to the OligoMiocene age to the unit (Nogueira and Ramos, in prep.). Moreover, all these also contributed for paleoenvironmental interpretations as shallow, clean and hot waters. In a more recent study of ostracods from the Pirabas Formation, Nogueira et al. (2011) showed the stratigraphical distribution of Haplocytheridea and Cytheridea genera in the upper part of Pirabas Formation correlated these levels with progradational cycles linked to the Miocene transgressive-regressive events of the Northeastern South America, in agreement with Fernandes (1984) and Távora et al. (2007).

Although there are advances in the stratigraphic and biostratigraphic studies providing a general knowledge of paloenvironment and age, a refined taxonomic study still is necessary to expand these informations in the Pirabas Formation. Among the ostracods genera recorded to this unit, Perissocytheridea is one of the most representative of transicional environments (lagoons, bays and estuaries). The number of Perissocytheridea's species recorded to Neogene in both South and Central America is relatively large (see the following papers and references therein: an extensive list of species related by Bold (1946, 1975a and b, 1981); Pinto and Ornellas 1970; Zabert 
1978; Purper 1979; Sheppard and Bate 1980; Muñoz-Torres et al. 1998 and Nicolaides and Coimbra (2008). Its occurrence has been very important to indicate transitional environments and brackish water facies with salinity fluctuations. This article describes new species of the genus Perissocytheridea: P. punctoreticulata n. sp., P. largulateralis n. sp., P. colini n. sp. and P. pirabensis n. sp; and presents the paleoenvironmental significance to the Pirabas Formation sections (outcrops and core) located at about 35 $\mathrm{km}$ from the town of Belém, Pará State, in the Bragantina plataform, northeastern coast of Brazil (Fig. 1).

\section{Geologic setting and Location}

The studied area is situated in the Bragantina platform, Pará State, north of Brazil where the crystalline basement occurs near the surface (Fig. 2A). Natural exposures are rare in this area, but there are open mines and boreholes that offer access. The area is represented mainly by the carbonate rocks of the Pirabas Formation that are exposed discontinuously superposed, at the top of the succession, by around $3 \mathrm{~m}$ of siliciclastic rocks from the Barreiras Formation (Rossetti and Góes, 2004). The Pirabas Formation is exposed along the coastal cliffs of northern Brazil and along roads and open-cast mines of the State of Pará, as well as of the States of Maranhão and Piauí and it is characterized by a complex association of facies, reflecting platform (inner to outer shelf) to coastal/transitional environments, including lagoons and mangroves (Góes et al., 1990). The mixed of siliciclastic-carbonate sediments from Barreiras and Pirabas Formations are interpreted as a related depositional sequences. Although facies organization records transgressive events, the distribution of stratal architecture indicates an overall progradational pattern. This is revealed by the superposition of the inner shelf with progressively more coastal environments (Góes et al., 1990), which resulted in increased input of siliciclastic lithologies (Rossetti et al., 2013).

Essentially, the sedimentary sequence of Pirabas Formation was accumulated in low-energy waters, although the presence of hummocky structures and glauconite indicates storm waves events (Rossetti and Góes, 2004). The presence of tidal channels, lagoons and tidal deltas also suggest a nearshore to shallow marine transitional platform environment (Rossetti, 2006). The analysis facies of this unit were interpreted based on previous works in which the paleoenvironmental context is closer to be a logoonal and estuarine over time according to the fossil record in general. Moreover, a recurrent 
progradacional process is distributed along the strata extending the shorelines. This pattern was also observed in the study by Nogueira et al. (2011) with the association of two ostracoda genera and the fossil assemblage that indicated a cycles of shallow marine (nearshore) to transitional (brackish water) setting, which resulted by the influx of freshwater from the continent and /or sea level negative oscilations. According to the most geological studies, this is revealed by the superposition of the inner shelf with progressively more coastal environments to the top of the unit (Góes et al., 1990).

One of the studied sections comprise of Miocene lagoonal/shallow marine

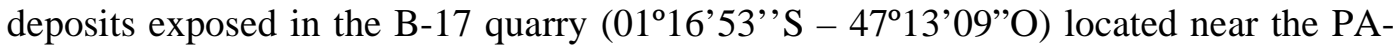
124 road (Fig. 2A, B and C) in the Capanema County. This section has about 20m thick and it is composed of limestones, sandstones, shales and marls. The other studied section comprise of Oligo-Miocene lagoonal/shallow marine deposits and is a core FPR-160 (0 ${ }^{\circ} 566^{\prime} 52,76$ "S - $\left.47^{\circ} 5^{\prime} 48,58^{\prime \prime} \mathrm{W}\right)$ which has $45 \mathrm{~m}$ depth and approximately $2 \mathrm{~km}$ away from the Primavera county (Fig. 2A and D). The basal portions of the core comprise a modified basis, with presence of green mica (muscovite) and a rift of carbonate matrix; thin limestone interbedded with gray marls and greenish portions with laminated appearance. In the middle portion presents a fine gray limestone with small marls and a medium gray limestone, fossiliferous. At the top, there is a thin middle, whitish, yellowish gray limestone, interbedded with marl, and a small middle bed of afriable fossiliferous and gray limestone; a portion of brown, green and sandy clay; and a fine sand selected dark and slightly clay (Source: Votorantim Cement, 2013).

\section{Material and methods}

The study material is composed of fifty seven samples (seven barrel samples) collected along of five different sections of the Pirabas Formation: twenty three samples are from the core FPR-160, in Primavera city, and the others thirty four are from the following sites (Fig. 6.1): B-17 quarry (nineteen samples), Ponta do Castelo (Fortaleza Island; five samples), Aricuru (Maracanã bay; six samples) and Atalaia (Salinópolis; four samples).

Samples were processed according to standard methods for calcareous microfossils in the Polishing Laboratory of the Museu Paraense Emílio Goeldi (MPEG) and Laboratório de Sedimentologia from Universidade Federal do estado do Pará (UFPA), Brazil; water bath was used to facilitate the desintegration of samples. Also the 
acetolysis method was used to desintegrate hardrocks samples from the Fortaleza Island and Atalaia sites, which method involves the insertion of $30 \mathrm{~g}$ of sediments in $100 \mathrm{ml}$ $(10 \%)$ of acetic acid for 12 hours. The samples were washed subsequently with deionized water and sieved (Rodrigues et al. 2011). Specimens of ostracods both youth and adults were picked from the $0.250 \mathrm{~mm}$ sieve mesh using a Zeiss Stereo Microscope. Micrographic images were taken using LEO model 1450VP Scanning Electronic Microscope at Museu Paraense Emílio Goeldi (MPEG), Pará, Brazil and also PHILIPS model/FEI (XL30) Scanning Electron Microscope (SEM and ESEM) at Smithsonian Institution National Museum of Natural History (NMNH).

All figured specimens are housed in the collection of the Museu Paraense Emílio Goeldi, Belém (Inv. No. MPEG-515-M to MPEG-548-M). The bibliography survey for taxonomic classification was based on the "Index of Non-Marine and Marine Ostracoda" of Kempf (1986), "Ellis and Messina” Catalogue (1965) and a numbers of specialized bibliographies, mainly papers of Bold since 40s to 80 s were also used.

To the taxonomic comparisons, the type material of the Howe Collections (HVH, Louisiana State University Museum), as well as the type material of the Bold (Louisiana State University Museum) and type-material stored at the Smithsonian Institution (US Natural History National Museum) also were examined: Perissocytheridea alata Bold, 1970 (HVH8727) and the species Perissocytheridea cribrosa (Klie 1933) (HVH10939) compared in the present study.

\section{Results}

Eleven species of the genus Perissocytheridea were described as cited previously, and suprageneric classification follow Liebau (2005). Abbreviations were used: $\mathrm{C}=$ carapace; $\mathrm{RV}=$ right valve; $\mathrm{LV}=$ left valve; $\mathrm{H}$ : height, $\mathrm{L}$ : length and $\mathrm{W}$ : width (in the text and plate legends).

\subsection{Systematic Paleontology}

Subclass OSTRACODA Latreille, 1806

Order Podocopida Sars, 1866

Suborder Cytherocopina Gründel, 1967

Infraorder Nomocytherinina Liebau, 1991 
Superfamily Cytherideoidea Liebau, 2005

Family Cytherideidae Sars, 1925

Subfamily Perissocytherideinae Bold, 1963

Tribu Perissocythereidini Van den Bold, 1963

Genus Perissocytheridea Stephenson, 1938

Perissocytheridea punctoreticulata n. sp.

Fig. 3.1-8

Material: 2 carapaces and 11 valves.

Etymology: Latin, punctae $=$ punctuation, refers to the strong punctuation of the surface; reticulum $=$ reticles, refers to the discret reticulation in the central portion of the carapace.

Holotypes: MPEG-515-M, Female, C; LV: L: $0.47 \mathrm{~mm}$ and H: $0.25 \mathrm{~mm}$; RV: L: 0.46 mm and H: $0.24 \mathrm{~mm}$, sample B12. MPEG-516-M, Male, C; LV: L: $0.48 \mathrm{~mm}$ and H: $0.24 \mathrm{~mm}$; RV: L: $0.47 \mathrm{~mm}$ and H: $0.23 \mathrm{~mm}$; Dorsal: L: $0.25 \mathrm{~mm}$ and $\mathrm{W}: 0.50 \mathrm{~mm}$, sample B12.

Paratypes: MPEG-517-M, RV: L: $0.50 \mathrm{~mm}$ and H: $0.26 \mathrm{~mm}$, sample B12. MPEG-518M, LV: L: $0.44 \mathrm{~mm}$ and H: $0.24 \mathrm{~mm}$, sample B11A.

Diagnosis: Ornated with primary and secondary reticulations, more punctated in the anterior region; 3 to 4 tansversal ridges in the posterodorsal region and two or three straight longitudinal rigdes extended from the central to the posteromedian region.

Description: Carapace medium and subrectangular. LV slightly overlaps the RV. Maximum height at the antero median region. Dorsal margin almost straight in lateral view and sinuous to slightly convex in the area coincident with the median shallow sulcus. Ventral margin slightly convex in both valves, upturned in the end. Anterior margin slightly rounded and slightly truncated in the anterodorsal region. Posterior margin narrow, slightly truncate to afilated, turned downward with caudal process more evident in the females. Dorsal view subelongate, larger in the posteromedian portion with alar processes evident; strong marginal border. Surface ornated with primary and secondary reticulations, more punctated in the anterior region; reticles with muri rounded, more strongly marked in the median region; two or three straight longitudinal rigdes extending from the central to the posteromedian region. Additional 3 or 4 delicate transversal ridges mainly in the posterodorsal region. Ventral rigde discret or discret alar process. It presents two lateral sulci, beginning in the first-third of the dorsal 
margin: one very short and shallow running parallel to the anterior margin and another very discret, almost straight running downward and reaching the ventral ala. Border discrete, compressed in the anterior and posterior margin. Ocular tubercle discret, smooth in the surface. Internal features typically of the genus. Sexual dimorphism present: females shorter, higher and with a caudal process more pointed than males.

Remarks: the species here described is closest to the species is Perissocytheridea largulateralis $\mathrm{n}$. $\mathrm{sp}$. described herein, but differs with a more punctuate and delicate carapace, subrectangular and more elongate in lateral view; ornamentation pattern more weakly reticulated in the posteromedian region, ocular tubercle less evident and consequently the sulcis are swallower than in the $P$. largulateralis. Moreover, this species resembles to the Perissocytheridea brachyforma Swain, 1955 mainly in the mature shell in general outline, but differs in the ornamentation pattern and more elongate carapace.

Distribution: Lower Miocene, Pirabas Formation, Pará State, Brazil.

Occurrence: B-17 quarry, Capanema, Pará (samples B11, B12 and B11A); drill core FPR-160 Primavera (sample AM.08). These samples are composed of gray shales and marls characterized in this paper as samples that arise within the brackish water facies.

\section{Perissocytheridea largulateralis $\mathrm{n} . \mathrm{sp}$.}

Fig.3.9-17

Material: 32 carapaces and 48 valves.

Etymology: Latin, largu = broad, large; due to the broad and robust carapace; lateralis $=$ lateral; refers to the be robust carapace in lateral view.

Holotype: MPEG-519-M, Female, C; LV: L: $0.48 \mathrm{~mm}$ and H: $0.30 \mathrm{~mm}$; RV: L: 0.50 mm and H: $0.28 \mathrm{~mm}$; dorsal view: H: $0.49 \mathrm{~mm}$ and W: $0.28 \mathrm{~mm}$, sample B13.

Paratypes: MPEG-520-M, Male, C; LV: L: $0.59 \mathrm{~mm}$ and H: $0.30 \mathrm{~mm}$; RV: L: $0.56 \mathrm{~mm}$ and $\mathrm{H}: 0.28 \mathrm{~mm}$; dorsal view: $\mathrm{H}: 0.54 \mathrm{~mm}$ and $\mathrm{W}: 0.30 \mathrm{~mm}$, sample B11A. MPEG-521M, LV: L: $0.55 \mathrm{~mm}$ and H: $0.28 \mathrm{~mm}$, sample B12. MPEG-522-M, RV: L: $0.49 \mathrm{~mm}$ and H: 0.25 mm, sample FPR-160 core, AM. 8 .

Diagnosis: Carapace subquadrangular, widely rounded and robust in lateral view. Heavy, strong and coarse ornamentation. Surface with two sinuous longitudinal ridges extending from the central to the posteromedian region. Evident alaform ventral rigde. 
Description: Carapace medium, subquadrate and robust, in lateral view. LV slightly overlapping the RV, mainly in the anterodorsal region. Dorsal margin relatively short and slightly sinuous, more angulated in the females; cardinal angles slightly evident. Ventral margin nearly straight with a discret oral concavity in both valves. Anterior margin widely rounded, extended below, truncate above. Posterior margin narrow and subacute with a small caudal process in the middle point in the lateral view. Midventrally a pronounced alarform ridge overlaps this margin forming a alar process. Maximum height at the anteromedian region, coincident with the ocular tubercle position. Surface strongly reticulated; more weakly punctated in the extremities, mainly in the anteromedian region. Surface with two sinuous longitudinal ridges arched in the middle. Ventrolaterally, one strong celated longitudinal alaform rigde forming the alar process. Ocular tubercle evident. Edge slightly pronounced smooth in the dorsal extremities in dorsal view and with a fine marginal border. A short and relatively deep antero transversal sulcus, behind of the ocular tubercle running downward parallel to the anterior margin. Median sulcus almost absent. Marginal rigde extending for all free margin. Sexually dimorphic: females are shorter and higher than males in side view. C shape differs in both, females are more subovate and males subrectangular to subelongate. Internal features typically of the genus.

Remarks: this species is similar to Perissocytheridea pirabensis $\mathrm{n}$. sp. mainly in the size, but differs in many aspects. Posteroventral region is slightly less turned up with more weakly marked cardinal posterior angle; ornamentation pattern mainly in the anterior region is almost smooth than reticulate, and the anterio sulcus shorter and less evident; central ridges more strongly marked. Moreover, this species resembles to the Perissocytheridea brachyforma Swain, 1955 mainly in general outline of the females and some aspects in the ornamentation pattern, but differs in the posterior margin in the $\mathrm{RV}$ more slopedown and in the dorsal margin of internal view more straight. In addition, Perissocytheridea brachyforma Swain subsp. Excavate Swain, 1955 also presents similarities mainly in general outline of the carapace, but differs in the ornamentation pattern.

Distribution: Lower Miocene, Pirabas Formation, Pará State, Brazil.

Distribution: Lower Miocene, Pirabas Formation, Pará State, Brazil.

Occurrence: B-17 quarry, Capanema, Pará (samples B1A, B2, B2A, B6, B11, B12, B11A, B11B, B13, B13A and B13B); core FPR-160 Primavera (sample: AM.08). These 
samples are composed of gray shales, and marls characterized in this paper as samples that arise within the brackish water facies; others sediments type presents laminate fine sandstone, medium sandstone, gray shales, marls, biocalcarenite and biocalcirrudite described within the brackish water and more saline water facies.

\section{Perissocytheridea colini $\mathrm{n}$. sp.}

Fig.4.1-6

Material: 4 carapaces and 2 valves.

Etymology: In honor of Prof. Jean-Paul Colin for his contributions to the study of the fresh and brackish water ostracods.

Holotypes: MPEG-523-M, C; LV: L: $0.36 \mathrm{~mm}$ and H: $0.21 \mathrm{~mm}$; RV: L: $0.36 \mathrm{~mm}$ and H: $0.19 \mathrm{~mm}$, sample B11. MPEG-524-M, C, dorsal view: H: $0.35 \mathrm{~mm}$ and $\mathrm{W}: 0.17 \mathrm{~mm}$, sample B11A.

Paratypes: MPEG-525-M, C, juvenile; LV: L: $0.33 \mathrm{~mm}$ and H: $0.16 \mathrm{~mm}$; RV: L: 0.32 $\mathrm{mm}$ and H: $0.16 \mathrm{~mm}$, sample FPR-160 core, AM. 8. MPEG-526-M, RV: L: $0.39 \mathrm{~mm}$ and H: 0.19 mm, sample FPR-160 core, AM. 8.

Diagnosis: small, thick-shelled and subovate carapace. Midventrally surface bears one alaform ridge with a knob in the end. A remarkable sulcus lies in almost dorso-median region, strongly marked in the females. Surface finely punctate; solae smooth.

Description: small, thick-shelled, and subovate carapace in adult forms and subrectangular in the juveniles forms. LV slightly overlaps the RV. Dorsal margin nearly straight in the LV, sinuous in the RV due to the convexity in the middle point coincident with the median sulcus, more evident in the females than in the males. Ventral margin almost straight with a discret anteromedian concavity in both valves; Anterior margin widely rounded, larger in the female than in the males; extended below, truncate above. Posterior margin truncate in dorsal and slightly pointed ventrally in the female and more elongate in the males with a very short caudal process sloping downward. Maximum height at the antero-median region. Surface finely punctuate almost smooth; solae smooth regularly for all surface, with flat margens. A remarkable sulcus at the mid-length lies from the dorsomedian to the central of carapace, more evident in the RV and in the females; slightly swallow immediately posterior to the sulcus. Antero dorsal sulcus discret. Dorsal view tumid in the mid-posterior portion and sub-acute extremities with short and smooth border. Midventrally surface bears one 
evident alaform ridge and posterior inflation with a knob in the end. Internal features typically of the genus.

Remarks: this species is similar to Perissocytheridea alata Bold, 1970 (HVH8727), however differs in the more truncate and tapered posterior end with subpyriform $\mathrm{C}$, beyond the straighter dorsal margin. The lack of ornamentation sets in Perissocytheridea cahobensis Bold, 1981 resembles most others species studied here, but it differs for presenting a prominent sexual dimorphism, with slight difference in shape and larger size.

Distribution: Lower Miocene, Pirabas Formation, Pará State, Brazil.

Occurrence: B-17 quarry, Capanema, Pará (samples B4, B11 and B11A); drill core FPR-160 Primavera (sample AM.08). These samples are composed of gray shales, marls, laminate fine sandstone and biocalcirrudite described within the brackish water and more saline water facies.

\section{Perissocytheridea pirabensis $\mathrm{n}$. sp.}

Fig.4.7-17 and Fig.5.1-5

Material: 8 carapaces and 113 valves.

Etymology: in reference to its restrict occurrence in the Pirabas Formation.

Holotypes: MPEG-527-M, Female, C, LV: L: $0.46 \mathrm{~mm}$ and H: $0.26 \mathrm{~mm}$; RV: L: 0.43 $\mathrm{mm}$ and $\mathrm{H}: 0.22 \mathrm{~mm}$; dorsal view: $\mathrm{H}: 0.48 \mathrm{~mm}$ and $\mathrm{W}: 0.23 \mathrm{~mm}$, sample B12. MPEG528-M, Female, LV, L: $0.46 \mathrm{~mm}, \mathrm{H}: 0.26 \mathrm{~mm}$; RV: L: $0.43 \mathrm{~mm}$ and H: $0.22 \mathrm{~mm}$, sample B11B. MPEG-529-M, Male, LV: L: $0.51 \mathrm{~mm}$ and H: $0.23 \mathrm{~mm}$; RV: L: $0.49 \mathrm{~mm}$ and $\mathrm{H}: 0.22 \mathrm{~mm}$, sample B11A.

Paratypes: MPEG-530-M, C; LV: L: $0.47 \mathrm{~mm}$ and H: $0.23 \mathrm{~mm}$; RV: L: $0.47 \mathrm{~mm}$ and H: $0.21 \mathrm{~mm}$; dorsal view: H: $0.48 \mathrm{~mm}$ and $\mathrm{W}: 0.23 \mathrm{~mm}$, sample B13B. MPEG-531-M, Female, C, LV: L: $0.41 \mathrm{~mm}$ and H: $0.23 \mathrm{~mm}$; RV: L: $0.45 \mathrm{~mm}$ and H: $0.25 \mathrm{~mm}$; dorsal view: H: $0.42 \mathrm{~mm}$ and $\mathrm{W}: 0.23 \mathrm{~mm}$, sample B13B. MPEG-532-M, Female, C, LV: L: $0.47 \mathrm{~mm}$ and H: $0.26 \mathrm{~mm}$; RV: L: $0.44 \mathrm{~mm}$ and $\mathrm{H}: 0.26 \mathrm{~mm}$, sample B11A. MPEG533-M, Male, C, LV: L: $0.43 \mathrm{~mm}$ and H: $0.21 \mathrm{~mm}$; RV: L: $0.40 \mathrm{~mm}$ and H: $0.19 \mathrm{~mm}$; dorsal view: $\mathrm{H}: 0.49 \mathrm{~mm}$ and $\mathrm{W}: 0.28 \mathrm{~mm}$, sample B13B.

Diagnosis: two to three small dorsal vertival rigdes in the anteromedian region, deep and transversal antero median sulcus lies to about one third of the middle hight. Surface coarsely reticulated with few secondary reticulations between the ridges. 
Ventrolaterally, two longitudinal ridges in the median region and one discret alaform process.

Description: carapace medium, subquadrate to subrectangular, in lateral view. LV larger than RV, overlapping slightly in the margins. Dorsal margin nearly straight, sinuous in the male. Ventral margin convex to sinuous, slightly concave in the ventroanterior, strongly angulated and upwards in the postrior. Anterior margin widely rounded, extended below, slightly truncate above. Posterior margin narrow, angulated and subacute with a pointed and short caudal process in the middle region. Maximum height at the anteromedian region. Surface coarsely reticulated with few secondary reticulations between the ridges mainly in the anterior region. Anterodorsal region smoother and with a discret ocular tubercle. In the dorsomedian region two or three short ridges extending below; the median rigde is deeper and longer than the others extending to the central area meeting the upper longitudinal rigde; subsequent to the ridges two to three small, deep and transversal sulci lies in the anteromiddle position, extendeding from the dorsal to $1 / 3$ of middle height, more visible in the males than in the females; in the anterior region, parallel to the anterior margin and behind of the discret ocular tubercle, other shorter, very shallow and discret sulcus. In the central region two longitudinal rigdes extending parallel to each other from the median to the posterior median region. The third rigde is shorter and extend from the ventro-median, turning up and join the median longitudinal rigde in the posterior quarter. Ventrolaterally, three longitudinal ridges runn from the anterior to posterior region where meet the discret alar process. The upper rigde extending from the anterior margin to the posterior where upturned and meet the median longitudinal rigdes. The median ridge is shorter than others. Sexually dimorphic: females are shorter and higher than males in lateral view. Internal features apparently typical of the genus. Inner lamellae of moderate width, broadest anteriorly; line of concrescence and inner margin considerably separated; canals pore sieved are few and widely spaced and are represented by rather large pits on interior and exterior valve surface. Dorsal view with anterior end subrounded and posterior end acute.

Remarks: this species is closest to Perissocytheridea largulateralis n. sp. (Fig.3.9-17) for having similarities in the shape of female carapace, but differs in the dorsal margin of the P. largulateralis that is more sinuous and convex in the region coincident with the anterior sulcus; and posteroventral region less curved upward; surface more 
punctated in the anterior region; dorsomedian sulcus almost absent, but with the alarform ridge more evident. Perissocytheridea aff. P. pumila Van den Bold, 1975 (Fig.5.7-14,) also presents similarities with the males specimens, in the carapace shape, but differs in posterior end presenting a caudal process more truncated and less pointed and; ornamentation pattern differenciated being more reticulated in the anterion region and reticles between the two ventral ridges. Paracytheropteron? pellegrinensis recorded by Ballent (1980) presents similarities mainly in the dorsal and internal view outlines, but differs in the ornamentation pattern and in the presence of a flatted and wide sulcus in the anteromedian position.

Distribution: Lower Miocene, Pirabas Formation, Pará State, Brazil.

Occurrence: B-17 quarry, Capanema, Pará (samples B11B, B12 and B11A). These samples are composed of gray shales, laminate fine sandstone and marls characterized in this paper as samples that arise within the brackish water facies.

Perissocytheridea aff. P. pumila Van den Bold, 1975

Fig.5.7-14

aff. 1975. Perissocytheridea pumila Van den Bold, pl.19, figs. 1-7, pp. 142, 143.

Not 1988 Perissocytheridea pumila Van den Bold, pl. 2, fig. 14.

Material: 7 carapaces and 9 valves.

Figured specimens: MPEG-534-M, Female, C; LV: L: $0.44 \mathrm{~mm}$ and H: $0.25 \mathrm{~mm}$; RV: L: $0.42 \mathrm{~mm}$ and $\mathrm{H}: 0.24 \mathrm{~mm}$; dorsal view: $\mathrm{H}: 0.45 \mathrm{~mm}$ and $\mathrm{W}: 0.23 \mathrm{~mm}$, sample B11B. MPEG-535-M, Male, C; LV: L: $0.47 \mathrm{~mm}$ and H: $0.23 \mathrm{~mm}$; RV: L: $0.45 \mathrm{~mm}$ and $\mathrm{H}$ : $0.22 \mathrm{~mm}$; dorsal view: H: $0.45 \mathrm{~mm}$ and $\mathrm{W}: 0.23 \mathrm{~mm}$, sample B11B. MPEG-536-M, RV: L: $0.42 \mathrm{~mm}$ and H: $0.22 \mathrm{~mm}$, sample B11A. MPEG-537-M, RV: L: $0.48 \mathrm{~mm}$ and H: $0.28 \mathrm{~mm}$, sample B11A. MPEG-538-M, RV: L: $0.44 \mathrm{~mm}$ and H: $0.21 \mathrm{~mm}$, sample B11B.

Description: medium, subrectangular to subelongate carapace, in lateral view. LV slightly larger than RV. Dorsal margin nearly straight in both valves. Ventral margin nearly convex to almost straight. Anterior margin obliquely rounded. Posterior margin narrow and subacute with a caudal process in the middle point. Midventrally it has an discret alarform ridge. Maximum height at the anterior end. Surface strongly reticulated: males more distinctly reticulate than females. Ocular tubercle prominent and near of the cardinal angle. A small and transversal sulcus lies on the anteromedian position behind of the ocular tubercle and run parallel to the anterior margin, being more prominent in 
the RV. Anteromedian sulcus relatively deep and discret, more evident in the RV. Evident longitudinal median ridge extending from the central region converging to the posterodorsal region in the $\mathrm{LV}$; in the $\mathrm{RV}$, and most in the female, this ridge extends from the posterodorsal region turndown to the ventral median region meeting the ventral rigde forming a loop. Ventral rigde parall to the margin that follows from the anterior region to the posterior, where it upturned and meet the median rigde. Dorsal view lens-shaped and robust, widest in the mid-posteriorly part; posterior end acute and anterior end subrrounded. Sexually dimorphic: females are shorter presenting subovate $\mathrm{C}$ and higher than males. Internal features typically of the genus.

Remarks: this species is very reminiscent to Perissocytheridea pumila Bold, 1975 mainly ventral margin almost straight in the RV and dorsal view with a antero-median small sulcus more prominent in the RV observed in the males forms, but differs in the ornamentation more distinctly reticulate, arrangement of the ridges with the distribution pattern of the ridge in the central region, dorsal view with posterior end narrow and absent of blunt spines in the anterior end. This species is also similar to Perissocytheridea sp. 4 described herein in many aspects as shape, size, and slightly in the ornamentation pattern, differing in the absence of the discret vertical anterior ridges; shorter ventral ridges and surface strongly reticulated.

Distribution: Lower Miocene, Pirabas Formation, Pará State, Brazil.

Occurrence: B-17 quarry, Capanema, Pará (samples B9, B11, B12, B11A and B11B); drill core FPR-160 Primavera (sample AM.08). These samples are composed of gray shales, marls and laminate fine sandstone characterized in this paper as samples that arise within the brackish water facies.

Perissocytheridea aff. P. brachyforma subsp. excavata Swain, 1955

Fig.5.15-17; Fig.6.1-3

aff. 1955. Perissocytheridea brachyforma subsp. excavata Swain, pl.62, figs.1a-c; tf. $33 b$, p.619 and 620 .

Material: 2 carapaces and 1 valve.

Figured specimens: MPEG-539-M, C; LV: L: $0.57 \mathrm{~mm}$ and H: $0.32 \mathrm{~mm}$; RV: L: 0.54 mm and $\mathrm{H}: 0.29 \mathrm{~mm}$; dorsal view: $\mathrm{H}: 0.54 \mathrm{~mm}$ and $\mathrm{W}: 0.26 \mathrm{~mm}$, sample B1A. MPEG540-M, LV: L: $0.52 \mathrm{~mm}, \mathrm{H}: 0.28 \mathrm{~mm}$; RV: L: $0.51 \mathrm{~mm}$ and H: $0.27 \mathrm{~mm}$, sample B11A. MPEG-541-M, RV: L: $0.51 \mathrm{~mm}, \mathrm{H}: 0.29 \mathrm{~mm}$, sample B11A. 
Description: medium and subpyriform carapace, in lateral view. LV larger than RV, overlapping slightly in the margins. Maximum height at the anteromedian region. Dorsal margin very slightly concave to sinuous in the LV, almost straight in the RV with a convex portion in the mid-dorsal margins in the RV. Ventral margin nearly straight slightly convex in the RV slightly sloped upward in the posterior. Anterior margin broadly rounded, extended below, truncate above. Posterior margin narrow and subacute with a caudal process in the middle point in side view. A deep anterodorsal sulcus lies parallel to the anterior margin and behind of the ocular tubercle. Ocular tubercle near of the cardinal angle. Median sulcus prominent extending to the central portion of the carapace, almost reaching the ventral rigde in the LV. Surface smooth. In both valves occurs clearly 5-6 longitudinal posterodorsal ridges occupy approximately middle half of the valve, all of which tend to converge in a posterior direction; of these, the ventral one begins about one-fourth from anterior end, extends posteriorly to about one-third from end where it curves abruptly dorsally and anteriorly as a hooked-shaped loop; the others longitudinal ridge are irregularly distributed, in some specimens two of the subdorsal ridges are connected posteriorly. Internal features not observed due to material scarcity and poor preservation.

Remarks: this species resemble to Perissocytheridea brachyforma subsp. excavata Swain, 1955 mainly in some aspects as shell subpyriform; dorsal margin nearly straight, but slightly sinuous; Anterior margin broadly rouded, extended below and subtruncate above. Posterior margin narrowly rounded to acuminate with a slightly dorso median short caudal process; longitudinal ridges pattern are the same, but differs in the sinuous form of these ridges and the ornamentation pattern with valve surface between ridges erratically pitted.

Distribution: Lower Miocene, Pirabas Formation, Pará State, Brazil.

Occurrence: B-17 quarry, Capanema, Pará (sample B1A and B11A). This sample is composed of biocalcarenite described within the more saline facies.

\section{Perissocytheridea sp. 1}

Fig.6.4-6

Material: 1 carapace.

Homotypes: MPEG-542-M, C; LV: L: $0.35 \mathrm{~mm}$ and H: $0.21 \mathrm{~mm}$; RV: L: $0.34 \mathrm{~mm}$ and H: $0.20 \mathrm{~mm}$; dorsal view: H: $0.37 \mathrm{~mm}$ and W: $0.17 \mathrm{~mm}$, sample FPR-160 core, AM.14. 
Description: small, subrectangular to subtriangular carapace, in lateral view. Dorsal margin nearly straight and angulate to the posterior region. Ventral margin almost straight to slightly convex. Anterior margin widely rounded. Posterior margin almost rounded, relatively wide and truncate with a short slope posteroventrally in lateral view. Surface ornated with swallow reticles almost punctated in the antero dorsal region, close to the sulcus area. Anterior region with very fine rigde extending from the anterodorsal region extending sinuously downwards and turning to the posteroventral region at the middle of the carapace. Very fine discret longitudinal ventral ridges. Two sulci in the anterodorsal region: one relatively deeper running parallel to the dorsal margin extending to the dorsomedian region where meet another deeper transversal sulcus that runs downwards to the central portion of the carapace meeting a rounded depression. Dorsal view rounded with fine marginal rigde. Maximum width at the anterior half. Internal features not observed.

Remarks: the species resemble to P. ornellasae Purper, 1979 recorded to the Miocene of Solimoes/Pebas formation, northweastern of Amazonia (Brazil), and Peru and Colombia (Muñoz-Torres et al., 1998), but differs on ornamentation pattern more strongly ornated and carapace shape more rounded and less elongate mainly in dorsal view.

Distribution: Lower Miocene, Pirabas Formation, Pará State, Brazil.

Occurrence: core FPR-160 Primavera (sample: AM.14). This samples is composed of marls characterized in this paper as samples that arise within the brackish water facies.

\section{Perissocytheridea sp. 2}

Fig.6.7-9

Material: 1 carapace.

Homotypes: MPEG-543-M, C; LV: L: $0.41 \mathrm{~mm}$ and H: $0.23 \mathrm{~mm}$; RV: L: $0.40 \mathrm{~mm}$ and H: $0.22 \mathrm{~mm}$; dorsal view: H: $0.38 \mathrm{~mm}$ and W: $0.20 \mathrm{~mm}$, sample FPR-160 core, AM.6.

Description: small and tumid carapace, subpyriform to subtriangular in lateral view. LV overlaps RV. Dorsal margin nearly straight in the LV, sinuous in the RV more noticeably with a slope to posteromidventrally. Ventral margin slightly sinuous, convex mainly in the region coincident with the alar process. Anterior margin rounded to truncate in the dorso. Posterior margin narrow and subacute with a evident caudal process pointing downward. Maximum height at the eye tubercle position and 
somewhat larger than half the length. Cardinal angle anterior prominent. Surface coarsely reticulate; roughly hexa-or pentagonal reticulae; solae smooth. Reticulation with less developed muri in the central and posterodorsal regions. Two sulci in the anterodorsal region: one relatively shallow running parallel to the dorsal margin extending to the dorso-median region where meet another weel marked and deeper transversal sulcus that runs downwards meeting the discret ventral ridge. This sulcus almost divided the carapace in two swallow portion, more evident in the anterior region of the RV. Internal features not observed. Alar process discret with a small node in the end.

Remarks: the species presents similarities to Perissocytheridea brachyforma Swain, 1955, Perissocytheridea swaini Benson and Kaesler, 1963 and Perissocytheridea japonica Ishizaki, 1968. The species P. brachyforma Swain, 1955 is similar mainly in immatures forms of the males' specimens, however, its size in adult forms is slightly larger ( $\mathrm{L} 0.50 \mathrm{~mm} ; \mathrm{H} 0.27 \mathrm{~mm}$ ), presenting in those forms a different outline, ornamentation and posterior end, besides having an prominent sexual dimorphism. $P$. swaini is similar in the shape, inflated, ovate and inflated in dorsal view, therefore it presents two posterior nodes, dorsal margin straight, $\mathrm{C}$ finely reticulate to punctuate in random pattern except in smooth anterodorsal portion and larger size. These features differ of the species herein studied. $P$. japonica is similar in shape, ornamentation pattern, shallow sulcus next to anterior margin among others; it differs in larger size (L $0.54 \mathrm{~mm} ; \mathrm{H} 0.29 \mathrm{~mm}$ ); and the presence of two and four shallow marginal ridges nearly and parallel to anterior margin. Due to the scarce material, this species was left in open nomenclature.

Distribution: Upper Oligocene, Pirabas Formation, Pará, Brazil.

Occurrence: FPR-160 core, Primavera (sample AM.06). These samples are composed of gray shales, laminate fine sandstone, and marls characterized in this paper as samples that arise within the brackish water facies.

\section{Perissocytheridea sp. 3}

Fig.6.10-12

Material: 4 valves.

Homotypes: MPEG-544-M, LV: L: $0.51 \mathrm{~mm}$ and H: $0.31 \mathrm{~mm}$, sample B7. MPEG-545M, RV: L: $0.48 \mathrm{~mm}$ and H: $0.27 \mathrm{~mm}$, sample B11A. 
Description: medium and subquadrate to suboval valves, in lateral view. LV larger than RV. Dorsal margin nearly straight in the RV, slightly convex in the LV mainly in the middle portion. Ventral margin almost straight to slightly convex and slope upward in the posterior region. Anterior margin obliquely rounded. Posterior margin narrow and subacute with a caudal process in the middle point in side view. Maximum height at the anterior end. Surface strongly reticulated in the porterior region, smoother to the anterior region; mainly reticulations between the ridges, but slightly punctated in the anterior region. Two main evident longitudinal ridges in the surface: one runn from the central portion to the postero dorsal region and the other parallel to the ventral margin, celated above; another third and more weak dorsal ridge extending parallel to the posterodorsal margin. Well marked anterodorsal sulcus running downward to the central portion where it meet the begin of the median rigde. Hinge typically for the genus.

Remarks: this species resemble to Perissocytheridea largulateralis $\mathrm{n}$. $\mathrm{sp}$. from the present study mainly in outline with highest in the anterior region; ventral ridge strongly pronounced presenting an arrangement of small and ridges secondaries which supports the ventral ridge, strongly reticulate between the ridges and also presence of anterior end rounded, however, differs in the median ridge pattern due to the presence of a single evident longitudinal ridge downward forming a loop and general arrangement of ridges.

Distribution: Lower Miocene, Pirabas Formation, Pará, Brazil.

Occurrence: B-17 quarry, Capanema, Pará (samples B7, B12, B11A and B11B). These samples are composed of gray shales, laminate fine sandstone and marls characterized in this paper as samples that arise within the brackish water facies.

\section{Perissocytheridea sp. 4}

Fig.6.13-15

Material: 4 valves.

Homotypes: MPEG-546-M, Female, RV: L: $0.48 \mathrm{~mm}$ and H: $0.27 \mathrm{~mm}$, sample B12. MPEG-547-M, Male, RV: L: $0.51 \mathrm{~mm}$ and H: $0.31 \mathrm{~mm}$, sample B11.

Description: medium and subovate valve in female to subelongate valve in males, in lateral view. Dorsal margin nearly sinuous in both valves with a convex portion in the anterodorsal margins in the hight of sulcus. Ventral margin almost straight. Anterior margin obliquely rounded, extended below, truncate above. Posterior margin narrow 
and subacute with a short caudal process in the middle point in side view. Maximum height at the anterior end. Surface strongly reticulated mainly between the ridges, more slightly reticulated in the anterior region. Evident median longitudinal ridge extending from the central to the postero median region. Midventrally alarform ridge with others 3 to 4 reticulated ridges above. Two sulcus: the median sulcus thin but well marked extending from the dorsal to ventral region; the other larger runn parallel to anterior margin. Hinge typically for the genus.

Remarks: the species has resemble to Perissocytheridea aff. P. pumila Bold, 1975 from the present study mainly in the same outline lens-shaped, however differs from this species in the coarsely ornamentation pattern and more robust shape. This species is higher and lenghter than $P$. aff. $P$. pumila presented in this paper.

Distribution: Lower Miocene, Pirabas Formation, Pará, Brazil.

Occurrence: B-17 quarry, Capanema, Pará (samples B12, B11A and B11B). These samples are composed of gray shales, laminate fine sandstone and marls characterized in this paper as samples that arise within the brackish water facies.

\section{Perissocytheridea sp.5}

Fig.6.16-18

Material: 4 carapaces.

Homotype: MPEG-548-M, C; LV: L: $0.66 \mathrm{~mm}$ and H: $0.31 \mathrm{~mm}$; RV: L: $0.63 \mathrm{~mm}$ and H: $0.29 \mathrm{~mm}$; dorsal view: H: $0.63 \mathrm{~mm}$ and W: $0.29 \mathrm{~mm}$, sample FPR-160 core, AM. 8. Description: medium, fragile and tumid carapace, subrectangular in lateral view. LV slightly larger than RV. Dorsal margin nearly straight in the LV, sinuous in the RV slightly convex in the dorso-median region. Ventral margin almost straight; and shows weakly cancavity anteromedially in both valves. Anterior margin rounded. Posterior margin narrow and subacute with a short caudal process. Ocular tubercle more discret in the RV. Maximum height at the anterior end. Surface delicately reticulated with secondary punctuations and canal pores sieved; the reticles are large and shallow with a number of longitudinal ridges extending from the anteromedian and from the posterior region in a radial shape converging to anteromedian, almost central constriction. Ventral margin with a narrow and delicate alarform ridge parallel to this margin; and others three discret ridges bellow extending parallel to this alarform. Two strongly marked sulci lies from the anterodorsal region: one in a more dorsal position, behind the ocular 
tubercle, is more evident running parallel to the dorsal margin, near to the cardinal angle; the other immediately posterior to the dorsal sulcus extending downwards to the median region. Narrow edge, discrete and more evident in dorsal view. Internal features not observed.

Remarks: the species closest is Perissocytheridea cribrosa (Klie, 1933) (HVH10939) from Recent of Caribbean (shallow and brackish water), which presents similarities as the size and the ornamentation pattern, but differs in the posterior region short and truncate, reticulations organized in pent- and hexagonal reticles with punctuations following them, anterodorsal region with a more smooth area and midventrally with out of the presence of a prominent longitudinal alaform ridge. It was left in open nomenclature due to loss of other specimens.

Distribution: Lower Miocene, Pirabas Formation, Pará State, Brazil.

Occurrence: B-17 quarry, Capanema, Pará (sample B11); FPR-160 Primavera core (samples AM.08 and AM.14). These samples are composed of marls characterized in this paper as samples that arise within the brackish water facies.

\subsection{Quantitative and qualitative analysis along of the studied stratigraphic sections}

Five stratigraphic sections were analyzed in this study: B-17 quarry, Atalaia (Salinas beach), Aricuru (Maracanã bay) and Ponta do Castelo (Fortaleza Island) outcrops, furthermore the FPR-160 Primavera Core (see map, Fig.1). However, only in B-17 quarry and in the FPR-160 Core stratigraphic sections were recorded the presence of Perissocytheridea.

Among the thirty six studied samples in both localities, five are barrel and the remaining yielded two thousand thirty six specimens of Perissocytheridea. In B-17 quarry, ten samples from the upper portion presented the highest frequency of genus, where the B11A is the most diverse and abundant. The lowest frequency were observed in the lower and middle portion of the section in the six samples. Regard to the core FPR-160, the sample with the highest frequency, diversity and abundance was AM. 8 while two others were less frequent as AM. 6 and AM. 14 (Tab. 1).

From the eleven species described in the present study, nine species where found in the B-17 quarry: Perissocytheridea colini n. sp., $P$. pirabensis n. sp., $P$. 
punctoreticulata n. sp., $P$. largulateralis n. sp., $P$. aff. $P$. pumila Bold, 1975, $P$. aff. $P$. brachyforma subsp. excavata Swain, 1955, P. sp. 3 P. sp. 4 and $P$. sp. 5.

In the core FPR-160, from a total of seventeen samples, only in three samples six species were recorded: P. punctoreticulata n. sp., P. largulateralis n. sp., P.colini $\mathrm{n}$. sp., $P$. sp. 1, $P$. sp. 2 and $P$. sp. 5. The species common in both stratigraphic sections were P. largulateralis n. sp., P.colini n. sp., P. punctoreticulata n. sp. and P. sp. 5 (Fig. 8).

The species more abundant in B-17 quarry were P.largulateralis n. sp. and $P$. pirabensis $\mathrm{n}$. sp., and the less abundant were Perissocytheridea aff. P. brachyforma subsp. excavata Swain, 1955, P. sp.1, P. sp. 2, P. sp. 3 and P. sp. 4. On the other hand, in the core FPR-160 only the species P. sp. 5 is more abundant (Fig. 8).

In two specific levels from the B-17 quarry (B11 and B12) where the Perissocytheridea occurs, the Elphidium and Ammonia genera were also found in abundance. The same to the AM. 8 sample from the FPR-160 core (Fig. 8). 


\subsection{Stratigraphic and paleobiogeographic distribution}

The ostracod fauna from Pirabas Formation sections has a high generic diversity, including a number of undescribed new species. The species of Perissocytheridea recognized here are new to the science and it is the first record of this genus in this formation increasing significantly the knowledge of the fossil diversity from Neogene of South America and also to contributing to the paleoenvironmental evolution.

The Perissocytheridea genus has a Gondwana origin. On the Africa (Szczechura et al., 1991; Colin et al., 1996; Andreu, 1996; Bassiouni, 2002; Mebrouk et al., 2011); South America continents (Uliana and Musacchio, 1978; Ballent, 1980; Viviers et al., 2000), in the Europe (Babinot 1985; Babinot, 1988; Babinot et al. 1996), it bas been known to the Cenomanian.

According to Babinot et al. (1996), the brackish-water genus Perissocytheridea Stephenson is well known from Miocene deposits and still living today in the northwestern and southwestern Atlantic (Grigg and Siddiqui, 1993; Whatley et al., 1995), seems during this period to have been restricted in Europe to the Dinaro Hellenic domain in Greece, Slovenia (Babinot and Colin, 1992). It should be noted that this genus is also known from this period in the so-called 'Afro - Arabic' province according Babinot (1985).

In South America, the first fossil record of Perissocytheridea in the Neogene was by Zabert (1978) that despite of the dubious taxonomical identification described three new species from the Upper Miocene of the Parana Formation in Santa Fé Province, Argentina Republic: Perissocytheridea victoriensis, Perissocytheridea alvareziana and Perissocytheridea ornata. These species were recorded in clays sediments interbedded with thin limestone layers; in addition, green-gray clays and sands. Others Neogene records were to the species Perissocytheridea formosa and Perissocytheridea? elongata described to the Plio-Pleistocene among the Pebas beds, in the Amazonian region, in Pichua from Peru and CAE/GEO/33 from Colombia (Sheppard and Bate,1980). Purper (1979) recorded the occurrence of Perissocytheridea in Miocene sediments from the Solimões Formation, in Brazil, which was also recorded to the correlated Pebas Formation, on Peru and Colômbia beds by Muñoz-Torres et al. (1998). These authors recorded the following species: Perissocytheridea ornellasae Purper, 1979 and Perissocytheridea acuminata Purper, 1979, Perissocytheridea akistron and Perissocytheridea sp.1. The most recent study was in the Yecua Formation 
from Bolivia by Nicolaidis and Coimbra (2008) which dated the studied section on Middle-Late Miocene and reported one new species: Perissocytheridea carrenoae.

At least to the present data, the Perissocyheridea genus has an extensive stratigraphic range from Cretaceous to Recent (Fig. 9). In the modern distribution, this genus presents rich records mainly during Pliocene to Recents sites around the world (Ishizaki, 1968; Guan, 1978; Cronin, 1988, Dias-Britto et al. 1988; McKenzie and Swain, 1967; Swain, 1967; Pinto and Ornellas, 1970; Ornellas, 1974; Keyser, 1977; Garbett and Maddocks, 1979; Bold, 1990; Teeter, 1995; Medley et al., 2007; Coimbra et al., 2007; see also Fig. 9). However, particularly in the Neotropical region, the records of this genus are quite covered mainly during the Cretaceous and Miocene actually (Viviers et al., 2000; Muñoz-Torres et al., 1998; Nicolaidis and Coimbra, 2008; Gross et al., 2013; Piovesan et al. 2014; 2015). On the other hand, records in the Europe has been increasingly known (Babinot and Colin, 1992; Babinot et al., 1996; Piovesan et al. 2015). Moreover, its occurrence is still unknown mainly in the Oligocene, Upper Eocene and Paleocene (Fig. 9). In general, the records of this genus are considerably significant within the Miocene and Recent sediments (Fig. 9). The species recorded by Bold (1988) from the Neogene of the Dominican Republic, only P. alata Bold, 1946 has its record confirmed to Lower Miocene; P. ? haitensis Bold, 1981 and P. pumila (Bold) is still uncertain (Fig. 9).

Neverthelless, the Cretaceous was a period in which this genus started its radiation when it became more abundant. Although there is the difficulty in taxonomy identification of some species in the geological record, even still need further studies to investigate the real occurrence and distribution over time of the genus.

\subsection{Paleoecological and Paleobiogeographical considerations}

In modern studies records, environmental preferences of Perissocytheridea species are typically of brackish water facies represented by lagoons system, estuaries, bays, lakes and coastal systems with both fluvial and marine influence, thus it can to occur with both freshwater and marine genera, but specially related to dominant genera mixohalines (Tab. 2, Tab. 3).

As also in older sediments, this genus usually is associated to those environments, as well as in hypersaline lagoon associated to Cyprideis including species of Aurila Cythereis, Basslerella, Cytheretta and Paracytheridea and Haplocytheridea 
(Curtis, 1960; Bold, 1963; Bold, 1971; Bold, 1972a, Howe and others, 1935; Sandberg, 1964, Purper, 1979).

The presence of Perissocytheridea in marine and non-marine environments is observed (Kempf 1986), although its occurrence be mainly in places of mixohaline influence and it is considered an excellent indicator of meso-polyhaline environments (Ornellas, 1974).

Concerning to the data from the Gulf of Mexico bays, species of this genus disappears totally when the salinity approach 30 psu (Practical Salinity Units) (Garbett and Maddocks, 1979; Colin et al., 1996). In Florida, this genus is oligo- to polyhaline, rather mesohaline (Keyser, 1977; see Tab. 3).

The association Perissocytheridea-Cyprideis also is recorded into the fauna consisted by benthic foraminifera such as Elphidium, Eponidella and Ammonia supporting the brackish water conditions (Madeira-Falcetta, 1974; Boltovskoy, 1990; Geslin et al., 1998). This fauna is generically similar to that one found in the brackish water lagoonal environment where Cytherura and Cytheromorpha genera may also be found (Sandberg, 1964). As also recorded in samples from units of the Enriquillo Basin from Dominican Republic where differences in frequency that association and more the presence of Elphidium and Ammonia along the stratigraphic sections suggested a reduce-salinity environment; and further marginal marine conditions (Mann, 1999).

The Yucatán Peninsula and surrounding areas (Guatemala, Belize and Mexico), displays inferred conductivity as the main factor that influences ostracode distribution and contribute to infer past climate and environmental changes. PerissocytherideaCyprideis association was also recorded in these regions where some species of Perissocytheridea tolerated low conductivity which inferred that this species is apparently independent of others environmental variables (Pérez et al., 2011; Tabs.2 and 3). This region also display ostracode species in common with SW Florida (Keyser, 1976).

Although Cyprideis is normally associated to species of Perissocytheridea, it has been recorded more commomly in brackish water, despite of being recorded in freshwater lakes (Wouters and Martens, 1992; 1994) and paleolakes (Ramos, 2006). Particularly, in South America, studies described species of Perissocytheridea with the same associations (Nicolaidis and Coimbra, 2008; Piovesan et al., 2014; Bertels and Martínez, 1990 and 1997). In addition, the occurrence of Perissocytheridea species 
from South America were compared to a species recorded in Portugal (Europe) associated to the Fossocytheridea and others marine ostracods. In each locality, the Perissocytheridea species corresponded differents responses to the tolerance of salinity gradients related more to the ecology of each species than to the genera (Piovesan et al., 2015).

\section{Discussion}

Based on all the results obtained, the uppermost stratigraphic samples in the B17 quarry and in the lower portions of the drill core Primavera (FPR-160) where a higher abundance of the genus Perissocytheridea occur, can be consider the lagoon where also similar association were found. Hence, this is most abundant mainly in the shales (which is a soft, finely stratified sedimentary rock that formed from consolidated calcareous mud and can be split easily into fragile laminations), marls as the sample B12 from B-17 quarry and AM. $8(\sim 36 \mathrm{~m})$ from FPR-160 Primavera core; marls with interbedded laminates fine sandstones (B11 and B11A) and marls (B11 and B11B). Rossetti et al. (2013) interpreted these fine-grains sedimentary packages samples as being lagoon environments.

In the studied sections generally, the samples that appear with the highest proliferation of associations previously discussed denote periods of reduced salinity. Furthermore, the foraminifera Elphidium and Ammonia occur together in those samples more abundant, as well as few Cyprideis species supporting the significant mixohaline influence in the lagoon (Fig.10D, E, I and J; Fig.7.1-14). In opposite, Haplocytheridea is assigned to euryaline behavior and indicative of shorelines, as well as Cytheridea infering that there are phisic-chemistry variations as salinity changes throughout the studied stratigraphic section. Cytheridea is a brackish to marine (epi-neritic) genus and has a habitat similar to that of Haplocytheridea (Sohn, 1951; Morkhoven, 1963; Swain, 1963; Marlz and Triebel, 1970; Puckett, 1994; Faranda et al., 2008; Stephenson, 1945; Bold, 1972a; Keen, 1977; Besonen, 1997). In addition, the paper published more recently by Nogueira et al. (2011) brings also an approach about the occurrence of Haplocytheridea and Cytheridea from northern Brazil in mixohaline environment related to transgression cycles trend.

During the Cretaceous to Recent, the Perissocytheridea-Cyprideis association can occur with both, fresh and marine ostracods, in paleoenvironmental salinity 
oscilations generally between infralitoral to lagoonal from coastal platform (Garbett and Maddocks, 1979; Cronin, 1988; Andreu, 1996; Morsi and Wendler, 2010), but also in non-marine (Uliana and Musacchio, 1978; Colin et al., 1996; Nicolaidis and Coimbra, 2008; Gross et al., 2013). These genera associated with marine ostracods, have also been found in hyperhaline environments (Neale, 1988). Previous studies show this association is similar to Perissocytheridea-Fossocytheridea found during Cretaceous (Piovesan et al., 2014; 2015).

The Perissocytheridea-Cyprideis association has a more mixohaline character present in those intervals here studied reinforced by a higher abundance and diversity of Perissocytheridea, more particularly in the uppermost portion from B-17 quarry. Meanwhile, in the other intervals, which the occurrence of this genus is insignificant, the genera marine are dominated. The high diversity of Perissocytheridea probably is related to the recurrence of the paleoenvironmental conditions along the time that allowed the high speciation of this genus and associated genera.

In this context, this association was recorded with marine genera in those intervals contributed to understanding the paleoenvironmental dynamics. Although the presence of marine genera are more diverse and abundant than brackish genera in those samples, and the high and restricted occurrence of Perissocytheridea in those intervals, allowed to conclude that there was, in that portion, a salinity fall or excessive increase of salinity. It is also important to note that those samples with a higher abundance of Perissocytheridea are the same of Haplocytheridea and Cytheridea in the B-17 quarry (Fig.10A-C).

Among marine genera abundant were Bairdoppilata after Haplocytheridea followed by Cytheridea, and in minor proportion Quadracythere, Cytheretta, Paracypris, Cytherella, Pellucistoma, Loxoconcha and Xestoleberis. These genera are normally recorded in lagoonal environments and associated to barrier reefs deposits (Bold 1970a; Whatley and Watson, 1988). However, they can also occur in "open sea" (Coimbra and Carreño, 2002) suggesting an environmental dynamics and that close to the coast.

The Perissocytheridea-Haplocytheridea-Cytheridea association is abundant in the lower and upper part of the Pirabas succession, particularly in the 40-35m interval of core FPR-160 and in the B-17 quarry. This association is largely related to the salinity decrease with the occurrence of brackish waters in interval throught the entire 
depositional setting (Fig. 10F-H). The ocurence of Elphidium and Ammonia foraminifera mostly combined with this ostracoda association corroborate with this interpretation. The recurrence of this association in the Pirabas succession indicate phases of salinization decrease probably related to continental waters inflow and/or sea level reduction (Fig. 10A-J). The absence of this ostracoda association in some intervals strongly indicate phases of normal salinity and/or maximum marine waters inflow (Phases I, II and IV in the FPR-160 core and phases I and II in the B-17 quarry). The salinity variation up section, provides from Perissocytheridea-HaplocytherideaCytheridea association combined with Ammonia and Elphidium, is tipically a characteristic of lagunar deposits probably inserted in a estuarine setting, as previously interpreted to the marls and biocalcarenite of B-17 quarry (Rossetti et al., 2013) and now extended to the FPR-160 core.

\section{Conclusions}

Eleven Perissocytheridea species were identified for the first time in the OligoMiocene Pirabas Formation: Perissocytheridea punctoreticulata n. sp., P. largulateralis n. sp., $P$. colini n. sp., $P$. pirabensis n. sp., $P$. aff. $P$. brachyforma subsp. excavata, $P$.aff. P.pumila, P. sp. 1, sp. 2, sp. 3, sp. 4 and sp. 5. In Brazil, the fossil record to this genus has been to the northwestern and northeastern regions and since the Cretaceous to Recent being this the first record to the Neogene northern Brazil. In addition, this high number of species probably is related to the recurrence of the paleoenvironmental conditions along the time.

The species P.aff. P.pumila and P. aff. P. brachyforma subsp. excavata present affinities with the Caribbean, Central and North America species as well as the association with Haplocytheridea and Cytheridea where they are generally associated with Perissocytheridea species. Cytheridea and Haplocytheridea are genera that support salinity variation. Although these genera occurs in the Pirabas succession into all facies related to brackish and marine waters deposits, Perissocytheridea is more abundant in the brackish water deposits, mainly in the lower and upper portion of Pirabas succession. The co-occurrence of the foraminifera Elphidium and Ammonia with Perissocytheridea-Haplocytheridea-Cytheridea association supports the significant mixohaline influence. Additionally, the recurrence of this ostracoda association in the 
Pirabas succession clearly indicate phases of lower salinity in the lagoon and/or negative sea level oscilations, confirming previous sedimentogical interpretations.

The paleobiogeographical distribution of genus Perissocytheridea is extended to northeastwards of Neogene Amazonia, Brazil. The new information herein provided by the fossil ostracods of Pirabas Formation is just another piece for this biogeographic puzzle, highlighting the crucial role for understanding the biogeographical history of the ostracofauna during the Neogene.

\section{ACKOWLEDGMENTS}

We would like to express our sincere gratitude to curators Gene Hunt, Ostracoda Collection of the Smithsonian Institute (National Museum of Natural History) and Lorene Smith of the Louisiana State University Museum of Natural Science for having me and enable analyzes of species types; to Professor Dr. Afonso César Rodrigues Nogueira (UFPA, Brazil) and to Dr. Orangel Aguilera (Universidad Francisco de Miranda/Venezuela) for the discussions and logistics support. To the VOTORANTIM for cession of the core FPR-160. To CNPq (The Brazilian Scientific and Technology Developing Council) for financial support (proc. 140850/2011-2) during the $\mathrm{PhD}$ and thanks Coordenação de Aperfeiçoamento de Pessoal de Nível Superior for the research grant received during the development of this study (CAPES/PDSE, Proc. $n^{\circ} 7284 / 13-6$ ) for giving me the opportunity to visit the largest collection globally recognized the Smithsonian Institution (NMNH) which enabled the development of this paper. 


\section{REFERENCES}

Andreu, B., 1996. Nouvelles espèces d'ostracodes du Turonien supérieur (?)-Coniacien (?)-Santonien de la région de Boulmane, Moyen Atlas, Maroc. Systématique, biostratigraphie et paléoécologie, paléobiogéographie des associations. In: JARDINÉ S., de KLASZ I. \& DEBENAY J.-P. (éds.), Géologie de l'Afrique et de l'Atlantique Sud. - Bulletin des Centres de Recherche Exploration-Production ElfAqui-taine, Pau, Mémoire 16, p. 483-509.

Babinot, J.-F., 1988. Données préliminaires sur les associations d'ostracodes du Cénomanien de Grèce (Zone sub-pélagonienne, Argolide). Implications paléobiogéographi-ques et géodynamiques. Geobios, Lyon, ${ }^{\circ} 21$, fasc. 4, p. 435463.

Babinot, J.-F. and Colin J.-P., 1992. Marine ostracode provincialism in the Late Cretaceous of the Tethyan realm and the Austral province. Palaeogeography, Palaeoclimatology, Palaeoecology $92,282-293$.

Babinot, J.-F., Colin, J.-P. and Tambareau, Y., 1996. Late Cretaceous non-marine ostracods from Europe: biostratigraphy, palaeobiogeography and taxonomy. Cretaceous Research, 17, 151 - 167.

Babinot, J.-F. and Moissenet, E., 1985. Iberocypris, un nouveau genre d'ostracode du Maastrichtien continental d'Espagne . Revue de Micropaléontologie 27 , 231 238.

Ballent, S.C. 1980. Ostrácodos de ambiente salobre de la Formación Allen (Cretácico superior) en la Provincia de Río Negro (República Argentina). Ameghiniana, 17(1):67-82.

Bassiouni, M.A.A., 2002. Middle Cretaceous (Aptian - Early Turonian) Ostracoda from Si-nai, Egypt.- Neue Paläontologische Abhand-lungen, Dresden, Band 5, 123 p.

Bertels, A. and Martínez, D.E., 1990. Quaternary ostracodes of continental and transicional littoral-shallow marine environments. Courier Forschungsinstitut Senckenberg 123: 141-159.

Bertels, A. and Martínez, D. E., 1997. Ostrácodos holocenos de la desembocadura del arroyo Napostá Grande, sur de la provincia de Buenos Aires, Argentina. Revista Española de Micropaleontología, 29: 20-69.

Besonen, M.R., 1997. The Middle and Late Holocene Geology and Landscape 808 Evolution of the Lower Acheron River Valley, Epirus, Greece. University of Minnesota. Unpublished master's thesis, University of Minnesota, $161 \mathrm{pp}$.

Bold, W.A. van den., 1946. Contribution to the study of Ostracoda with special reference to the tertiary and cretaceous microfauna of the Caribbean region. DeBussy, Amsterdam, 167 pp. 
Bold, W.A. van den., 1950a. A checklist of Cuban Ostracoda. Journal of Paleontology. Vol. 24., No 1, January.

Bold, W.A. van den., 1950b. Miocene Ostracoda from Venezuela. Journal of Paleontology, Tulsa, 24 (1): 76-88.

Bold, W.A. van den., 1957b. Oligo-Miocene Ostracoda from southern Trinidad. Micropaleontology. 3 (3), 231-254.

Bold, W.A. van den., 1958a. Ostracoda of Brasso Formation of Trinidad. Micropaleontology, New York, 4 (4): 391-418.

Bold, W.A. van den., 1958b. Distribution of fresh-water ostracodes in Trinidad. Micropaleontology, vol.4, nno. 1, pp. 71-74, text-figs. 1-3, tables 1-5, january. Paleontology, 7: 1-105.

Bold, W.A. van den., 1960. Eocene and Oligocene Ostracoda of Trinidad. Micropaleontology, 6(2):145-196.

Bold, W.A. van den., 1963. Upper Miocene and Pliocene Ostracoda of Trinidad. Micropaleontology 9(4): 361-424.

Bold, W.A. van den., 1965. Middle Tertiary Ostracoda from northwestern Puerto Rico. Micropaleontology 11(4): 381-414.

Bold, W.A. van den., 1966a. Miocene and Pliocene Ostracoda from northeasterm Venezuela. Koninkl. Nederlandse Akad. Wetensch. Verh., Affi. Natuurk., ser. 1, 23(3), 43 p.

Bold, W.A. van den., 1966b. Ostracode zones in Caribbean Miocene. Bulletin A'rnerican Association of Petroleum geologists 50: 1029-1031.

Bold, W.A. van den., 1966c. Ostracoda Of The Pozón Section, Falcón, Venezuela. Journal of Paleontology, v.40, Nº 1, p. 177-185, PL. 22, 2 Text.-Figs., January.

Bold, W.A. van den., 1966d. Upper Miocene Ostracoda from the Tubará Formation (northern Colombia). Micropaleontology. 12 (3), 360-364.

Bold, W.A. van den., 1967. Ostracoda of the Gatun Formation, Panama. Micropal., 13(3): 306-318.

Bold, W.A. van den., 1969. Late Middle Eocene to Recent planktonic foraminiferal biostratigraphy. In: Proceeding of the Frist International Conference on Planktonic Microfossils, Geneva (1967) v. 1, p. 199-422.

Bold, W.A. van den., 1970a. The genus Costa (Ostracoda) in the Upper Cenozoic of the Caribbean Region. Micropaleontology 16 (1), 61-75.

Bold, W.A. van den., 1970b. Ostracoda of the Lower and Middle Miocene of st. Croix, St. Martin and Anguilla. Louisiana State University. March-June. Carib. J. Sci., 10(1-2).

Bold, W.A. van den., 1971. Ostracode Associations, Salinity and Depth Of Deposition In The Neogene Of The Caribean Region. In: Paléoecologie Des Ostracodes Pau 1971, France, Oerteli, H. J. (Ed.). Bull Centre Rech. Pau - Snpa. Vol. 5: 449-460 Pp.

Bold, W.A. van den. 1972a. Ostracoda of the La Boca Formation Panama Canal Zone. Micropaleontology 18 (4), 410-422. 
Bold, W.A. van den. 1972b. Ostracodes del Post-Eoceno de Venezuela y regiones vecinas. Boletin de Geologia, Ministerio de Energia e Hibrocarburos, publicacion Especial (Memoria del 4 Congresso Geológico Venezolano, Tomo 2), 5: 999 1071.

Bold, W.A. van den., 1975a. Ostracodes from the Neogene of Cuba. Bull. Amer. Pal., Ithaca, New York, vol. 68, no. 289, pp. 142-144.

Bold, W.A. van den., 1975b. Neogene biostratigraphy (Ostracod) of southern Hipanola. Bull. Amer. Pal., Ithaca, New York, vol. 66 (1974-1975), no. 286, pp. 610, 618620.

Bold, W.A. van den., 1981. Distribution of Ostracoda in the Neogene of Central Haiti. Bulletins of American Paleontology 79, no. 312: 136 p.

Bold, W.A. van den., 1988. Neogene paleontology in the northern Dominican Republic. The subclass Ostracoda (Arthropoda: Crustacea). Bulletins of American Paleontology 94(329): 1-105.

Bold, W.A. van den., 1990. Stratigraphical distribution of fresh and brackish water Ostracoda in the late Neogene of Hispaniola. In Whatley, R.C., Maybury, C., Eds., Ostracoda and Global Events, 221-232. International Symposium on Ostracoda 10. London: Chapman and Hall.

Boltovskoy, E., 1990. Morphological variations of benthic foraminiferal tests in response to change in ecological parameters: a review. Journal of Paleontology, 65:175-185.

Coimbra, J.C., Carreño, A.L. 2002. Sub-Recent Bairdiinae (Crustacea, Ostracoda) from the Brazilian Equatorial Shelf. Revista Española de Micropaleontología, 34(2): 187199.

Coimbra, J. C., Carreño, A. L., Geraque, E. A., Eichler, B. B., 2007. Ostracodes (Crustacea) from Cananéia-Iguape estuarine/lagoon system and geographical distribution of the mixohaline assemblages in southern and southeastern Brazil. Iheringia, Sér. Zool., Porto Alegre, 97(3):273-279.

Colin J.-P., Tambareau Y., Krasheninikov V.A., 1996. Ostracodes limniques et lagunaires dans le Crétacé supérieur du Mali (Afrique de l'Ouest): systématique, paléoécologie et affinités paléobiogéographiques. - Revue de Micropaléontologie, Paris, vol. 39, $\mathrm{n}^{\circ} 3$, p. 211-222.

Cronin, T.M. 1988. Ostracods and sea-level changes; case studies from the Quaternary of North and South Carolina, U.S. Atlantic Coast Plain. In: P. De Deckker; J.-P. Colin \& J.-P. Peypouquet (eds.) Ostracoda in the Earth Sciences, Elsevier, p. 77-88.

Curtis, D. M., 1960. Relation of environmental energy levels and ostracod biofacies in east Mississippi delta area. American Association of Petroleum Geologists, Bulletin 44: 471-494.

Dias-Brito, D.; Moura, J. A., Würdig, N. L., 1988. Relationships between ecological models based on ostracods and foraminifers from Sepetiba Bay (Rio de Janeiro Brazil). In: HANAI, T.; IKEYA, N. \& ISHIZAKI, K. eds. Evolutionary Biology of Ostracoda. Amsterdam, Elsevier. p.467-484. 
Ellis, S.J., Messina, A.R., 1940 et sequences. Catologue on ostracoda. The Micropaleontology Project, Micropaleontology Press Inc., New York: http:// micropress.org/e_m.html.

Faranda, C., Cipollari, P., Cosentino, D., Gliozzi, E., Pipponzi, G., 2008. Late Miocene ostracod assemblages from eastern Mediterranean coral reef com-plexes (central Crete, Greece). Revue de Micropaléontologie 51, 287-308.

Fernandes, J.M.G., 1984. Paleoecology of Formation Pirabas, Pará State. In: 33॰ Brazilian Congress of Geology. Anais da Academia Brasileira de Ciências SBG 1, 330-340 pp. (in Portuguese).

Fernandes, J. M. G., 1988. Bioestratigrafia da Formação Pirabas, Estado do Pará. In: 35º Congresso Brasileiro De Geologia, Anais da Academia Brasileira de Ciências. SBG, 1: 330-340.

Fernandes, M.J.G., Távora, V.A., 1990. Estudos Dos Foraminíferos Da Formação Pirabas Procedentes Do Furo Cb-Ufpa-P1 (85), Município De Capanema, Estado Do Pará. In: Congresso Brasileiro De Geologia, 33, Rio De Janeiro. Anais Da Academia Brasileira De Ciências, Rio De Janeiro: Sociedade Brasileira De Geologia, 1: 470-475.

Ferreira Penna, D. S., 1876. Breves notícias sobre os sambaquís do Pará. Arquivo do Museu Nacional, 1: 85-89.

Ferreira, C.S., 1977. Fácies Da Formação Pirabas (Mioceno Inferior): Novos Conceitos E Ampliações. Anais Da Academia Brasileira De Ciências, 49 (2): 353.

Ferreira, C.S., Fernandes, A.C.S., 1987. Indicadores de possível ambiente reci-fal na Formac são Pirabas, Oligo-Mioceno, N-NE do Brasil. 10॰ Congresso Brasileiro de Paleontologia, Resumos das Comunicac „ões. SBP, 1, 38.

Ferreira, C.S.; Macedo, A.C.M., Assis, J.F.P., 1978. A Formação Pirabas No Estado Do Pará - Novo Registro De Subsuperfície: Belém (Furo 4be-01-Pa, Cprm). Anais Da Academia Brasileira De Ciências, Rio De Janeiro, 50(3): 427.

Ferreira, C.S.M.; Vicalvi, A.; Macedo, A.C.M., 1981. Nota sobre a seqüência sedimentar ao sul do rio Guamá, Estado do Pará. Evidências do Oligo-Mioceno marinho, através dos resultados preliminares da sondagem feita em Vila Mãe do Rio, (“48”), BR-010, Município de Irituia. Anais da Academia Brasileira de Ciências, 53: 208-209.

Ferreira, C.S., Vicalvi, M.A., Macedo, A.C.M., 1984. Os limites meridionais da bacia de Pirabas. In: Congresso Brasileiro De Geologia, 33, Rio de Janeiro. Sociedade Brasileira de Geologia 1, Anais, Rio de Janeiro, p. 326-329.

Garbett E., Maddocks R.F., 1979. Zoogeography of Holocene Cytheracean ostracodes in the bays of Texas.- Journal of Paleontology, Tulsa, vol. 53, n 4, p. 841-919.

Geslin, E.; Debenay, J.-P., Lesourd, M., 1998. Abnormal wall textures and test deformation in Ammonia (hyaline foraminifer). Journal of Foraminiferal Research, 28:148-156.

Góes, A. M., Rossetti, D. F., Nogueira, A.C.R., Toledo, P. M., 1990. Modelo Deposicional Preliminar Da Formação Pirabas No Nordeste Do Estado Do Pará. Boletim Do Museu Paraense Emílio Goeldi, Série Ciências Da Terra, 2:3-15.

Grigg, E. M., and Siddiqui, Q. A., 1993. Perissocytheridea Stephenson , 1938 ; a brackish water ostracod . 2 nd European Ostracodologists Meeting, Glasgow , p . 257.

Gross, M., Ramos, M.I., Caporaletti, M., Piller, W.E., 2013. Ostracods (Crustacea) and their palaeoenvironmental implication for the Solimões Formation (Late Miocene; 
Western Amazonia/Brazil). Journal of South American Earth Sciences, 42, 216241.

Guan, S., 1978 Description of Ostracodes. In: H. P. I. of G. S. and other institutions (Ed), The illustrated Book on Paleontology of Middle South China, Part 4, Microfossils. Geological Publishing House, Beijing, pp. 1-765.

Hartmann, G., 1956. Zur Kenntnis des Mangrove-Estero-Gebietes von El Salvador und seiner Ostracoden- Fauna. Kieler Meeresforschungen, Kiel. J.: 21948. Taf.30·2.

Howe, H. V., others, 1935 - Ostracoda of the Arca Zone of the Choctawhatchee Miocene of Florida. Florida, Dept. Cons., Geol. Bull., no. 13, pp. 1-47, 4 pls.

Ishizaki, K., 1968. Ostracodes from Uranouchi Bay, Kochi Prefecture, Japan. Science Reports of the Tohoku University, Sendai, Second Series (Geology) 40, 1-45.

Keen, M.C., 1977. Ostracod assemblages and the depositional environments of the Headon, Osborne, and Bembridge Beds (Upper Eocene) of the Hamp-shire Basin. Palaeontology 5, Part 2, 405-445.

Kempf, E. K., 1986. Index and Bibliography of Marine Ostracoda: Index A and B. Sonderveroeffentlichungen des Geologischen Instituts der Universitaet zu Koeln, 51: 1-712, Koeln.

Keyser, D., 1976. Zur Kenntnis der brackigen mangrove bewachsenen Weichböden Su"dwest-Floridas unter besonderer Berücksichtigung ihrer Ostracoden fauna. Dissertation zur Erlangung des Doktorgrades des Fachbereichs Biologie. Universität Hamburg, Hamburg.

Keyser, D., 1977. Ecology and zoogeography of recent brackish-water ostracoda (Crustacea) from south-west Florida. In: LÖFFLER H. \& DANIELOPOL D. (eds.), Aspects of Ecology and Zoogeography of Recent and Fossil Ostracoda.- Dr W. Junk b.v. Publishers, The Hague, p. 207-221.

King, C. E. and L. S. Kornicker. 1970. Ostracoda in Texas bays and lagoons: an ecologic study. Smithson. Contrib. Zool. 24:1-92.

Klie, W., 1933. Zoologische Ergebnisse einer Reise nach Bonaire,Curacao und Aruba im Jahre 1930 NB 5.Sueßwasser-und Brackwasser-Ostracoden von Bonaire,Curacao und Aruba. Zoologisches J 64, 369-390.

Liebau, A., 2005. A revised classification of the higher taxa of the Ostracoda (Crustacea). Hydrobiologia 538:115-137.

Macedo, A. C. M., 1970. Sobre a distribuição de Ostracoda no Mioceno caribeano com um estudo especial sobre os ostracodes da Formação Pirabas, Pará, Brasil. Rio de Janeiro. Dissertação de Mestrado em Geologia - Programa de Pós-Graduação em Geologia, Universidade Federal do Rio de Janeiro. 62 p.

Macedo, A.C.M., 1971. Considerações sobre os ostracodes do Mioceno marinho do Estado do Pará. Anais da Academia Brasileira de Ciências, Rio de Janeiro. 43: $523-$ 528.

Macedo, A.C.M., 1983. Ostracodes como objeto de Pesquisa Paleontológica: Uma Experiência. In: Congresso Brasileiro De Paleontologia, 8, 1983b. Rio De Janeiro. Resumos Das Comunicações. Rio De Janeiro: Sociedade Brasileira De Paleontologia, P.72.

Macedo, A. C. M., 1985. Comentários sobre Ostracodes da fácies Castelo, Formação Pirabas, Estado do Pará. Anais da Academia Brasileira de Ciências, 57, 140.

Macedo, A. C. M., 1988. Autoecologia de ostracodes fósseis: problemas. Anais da Academia Brasileira de Ciências, 60, 111 p. 
Madeira-Falcetta, M., 1974. Ecological distribution of the camoebal and foraminiferal associations in the mixohalineenvironment of the southern Brazilian litoral. Anais da Academia Brasileira de Ciências, 46:667-687.

Mann, P., 1999. Caribbean sedimentary basins: Classification and tectonic setting from Jurassic to present, Caribbean Sedimentary Basins, Elsevier Sedimentary Basins of the World Series, Series Editor, K. Hsu, p. 3- 31.

Marlz, H; Triebel, E., 1970. Ostracoden aus dem Sannois und jOngeren Schichten des Mainzer Beckens, 2: Hemicyprideis n.g. Senckenbergiana Lethaea, Frankfurt,51 (I): 147, TaU-13.

Maury, C.J.,1925. Fosseis terciácios do Brasil com descrições de novas formas cretáceas. Monogr. Serv. Geol. Mineral. Brasil. Rio de Janaeiro, 4, 665 p.

Mebrouk, F., Colin, J.-P., Hennache, F., 2011. Un gisement d'ostracodes non-marins dans l'Éocène inférieur du Djebel Amour, Atlas saharien central, Algérie : taxonomie, paléoécologie et paléobiogéographie.- Carnets de Géologie / Notebooks on Geology, Brest, Article 2011/04 (CG2011_A04), p. 83-97.

Medley, P.; Tibert, N.E; Patterson, W.P.; Curran, H.A.; Greer, L., Colin, J.-P., 2007. Paleosalinity history of middle Holocene lagoonal and lacustrine deposits in the Enriquillo Valley, Dominican Republic based on pore morphometrics and isotope geochemistry of Ostracoda. Micropaleontology, 53:409-419. doi:10.2113/gsmicropal.53.5.409

Morkhoven, F.P.C.M. van, 1963. Post-Palaeozoic Ostracoda. Their Morphology, Taxonomy and Economic Use: Generic descriptions. Anisterdam, Elsevier. v.2, fig. 1-763.

Morsi, A.-M. M., Wendler, J.E., 2010. Biostratigraphy, palaeoecology and palaeogeography of the Middle Cenomanian-Early Turonian Levant Platform in Central Jordan based on ostracods. Geological Society, London, Special Publications; v. 341; p. 187-210.

Muñoz-Torres, F.A.; Whatley, R.C., Van Harten, D., 1998. The endemic non-marine Miocene ostracod fauna of the upper Amazonbasin. Revista Española de Micropaleontología, 30:89-105.

Neale, J.W., 1988. Ostracods and paleosalinity reconstruction. In: DE DECKKER P., COLIN J.-P. \& PEYPOUQUET J.-P. (eds.), Ostracoda in the Earth Sciences.Elsevier Science Publishers,Amsterdam, p. 125-155.

Nicolaidis, D. D., Coimbra, J. C., 2008. Perissocytheridea carrenoae sp. nov. (Crustacea, Ostracoda) and associated calcareous microfauna from Yecua Formation (Miocene), Bolivia. Revista Brasileira de Paleontologia, v. 11, p. 179-186.

Nogueira, A.E, Ramos, M.I.F., Puckett, T.M., 2011. The genera Haplocytheridea Stephenson, 1936 and Cytheridea Bosquet, 1852 (Subphylum Crustacea, Class Ostracoda) from the Early Miocene Pirabas Formation, Brazil. Revue de Micropaléontologie, 54: 215-235.

Ornellas, L.P., 1974. Minicythere heinii, gen. et sp. novo from Southern Brazil and a characteristic. Ostracode Association of Brackish water Environment. Anais da Academia Brasileira de Ciencias, Rio de Janeiro, 46 (3/4): 469-96, pl.1-1l, fig.1-2. 
Pérez, L., Frenzel, P., Brenner, M., Escobar, J., Hoelzmann, P., Scharf, B., Schwalb, A., 2011. Late Quaternary (24-10 ka BP) environmental history of the Neotropical lowlands inferred from ostracodes in sediments of Lago Petén Itzá, Guatemala. Journal of Paleolimnology, 17pp, DOI 10.1007/s10933-011-9514-0.

Petri, S., 1952. Ocorrências de Foraminíferos Fósseis no Brasil. Boletim da Faculdade de Filosofia, Ciências e Letras, USP, 134(7): 21-42.

Petri, S., 1954. Foraminíferos fósseis da Bacia do Marajó. Boletim da Faculdade de Filosofia, Ciências e Letras da Universidade de São Paulo (Geologia), 134: 1-172.

Petri, S., 1957. Foraminíferos Miocênicos da Formac, ão Pirabas. Boletim da Faculdade de Filosofia (Ciências e Letras, USP), 216 (16): 1-79.

Pinto, I., Ornellas, L.P., 1970. A new brackishwater ostracode Perissocytheridea krömmelbeini Pinto \& Ornellas, sp. nov., from southern Brazil. Escola de Geologia de Porto Alegre, Publicação Especial, 20:1-19.

Piovesan, E.K., Cabral, M.C., Colin, J.-P., Fauth, G., Trescastro, B. C., 2014. Ostracodes from the Upper Cretaceous deposits of the Potiguar Basin, northeastern Brazil: taxonomy, paleoecology and paleobiogeography. Part 1: Turonian. - Carnets de Géologie [Notebooks on Geology], Brest, vol. 14, nº 12, p. 211-252.

Piovesan, E.K., Cabral, M. C., Boavida, E. A., Colin, J.-P., Fauth, G., 2015. Fossocytheridea Swain \& Brown and Perissocytheridea Stephenson (Ostracoda): Insights Into Paleosalinity Gradients Of Late Cretaceous Deposits From Brazil And Portugal. Rev. bras. paleontol. 18 (1):21-30.

Puckett, T.M., 1994. New Ostracoda species from an Upper Cretaceous oyster reef, northern Gulf Coastal Plain, USA. Journal of Paleontology 68 (6), 1321-1335.

Purper, I., 1979. Cenozoic ostracodes of the Upper Amazon Basin, Brazil. Pesquisas, 12:209-281.

Ramos, M.I.F., 2006. Ostracods from the Neogene Solimões Formation (Amazonas, Brazil). Journal of South American Earth Sciences 21, 87-95.

Ramos, M. I. F., Távora, V. DE A., Pinheiro, M. P., Baia, N.B., 2004. Microfósseis. In: Rossetti, F. R. \& Góes, A. M (Eds.). O Neógeno Da Amazônia Oriental, Mpeg. P. 93-107.

Rodrigues, G.B.; Bom, M.H.H.; Fauth, G., 2011. Recovery of ostracods in Cretaceous dolomitic carbonate: The efficiency of acetolysis. Marine Micropaleontology, 92-93: 81-86.

Rossetti, D.F., 2000. Influence of low amplitude/high frequency relative sea-levels changes in a wave-dominated estuary (Miocene), São Luis Basin, northern Brazil. Sedimentary Geology, 133: 295-324.

Rossetti, D.F., 2006. Evolução Sedimentar Miocênica nos Estados do Pará e Maranhão. Revista do Instituto de Geociências, USP, 6(2): 7-18.

Rossetti, D.F., Góes, A.M., 2004. O Neógeno da Amazônia Oriental. Coleção Friedrich Katzer, Museu Paraense Emílio Goeldi, p. 225.

Rossetti, D.F.; Bezerra, F.H.; Dominguez, J.M.L. 2013. Late Oligocene-Miocene transgressions along the equatorial and eastern margins of Brazil. Earth-Science Reviews, 123: 87-112.

Sandberg, P., 1964. The ostracod-genus Cyprideis in the Americas. Stockholm Contributions in Geology, Stockholm, 12: 1-178, pl.1-23, fig.1-33. 
Sheppard, L., Bate, R., 1980. Plio-Pleistocene ostracods from the Upper Amazon of Colombia and Peru. Palaeontology, 23:97-124.

Sohn, I.G., 1951. Check list of salinity tolerance of Post-Paleozoic fossil Ostracoda. Journal of the Washington Academy of Sciences, Washington, 41 (2): 64-6.

Stephenson, M.B., 1945. Two new Ostracoda from subsurface surface Cook Mountain (Eocene) Strata of Texas. Journal of Paleontology 19 (4), 380-382.

Swain, F.M., 1955. Ostracoda of San Antonio Bay, Texas. Journal of Paleontology. Tulsa, Okla., 29 (4): 561-646, p1.59-64, and text-fig.1-39.

Swain, F.M., 1963. Pleistocene Ostracoda from Gubik Formation, Arctic Coastal Plain Alaska. Journal of Paleontology 37 (4), 798-834.

Swain, F.M., 1967. Ostracoda from the Gulf of California. Memoirs of the Geological Society of America 101, 1-139.

McKenzie, K.G. and Swain, F.M., 1967. Recent Ostracoda from Scammon Lagoon, Baja California. Journal of Paleontology 41, 281-305.

Szczechura, J.; Abd-Elshafy, E., Babinot, J.-F., 1991. Late Albian to Early-MidCenomanian ostracodes from Northern Galala Plateau, Egypt. Acta Paleontologica Polonica, 36:3-38.

Swain, F.M., Brown, P.M., 1964. Cretaceous Ostracoda from wells in the southeastern United States. Bulletin of North Carolina Department of Conservation and Development, 78:1-55.Sylvester-Bradley, 1948

Távora, V., Fernandes, J.M., 1999. Estúdio de los foraminíferos de la Formación Pirabas (Mioceno Inferior), Estado de Pará, Brasil, y su correlación con faunas del Caribe. Revista Geológica de America Central 22: 63-74.

Távora, V. A.; Silveira, E.S.F.; Milhomem Neto, J.M., 2007. Mina B-17, Capanema, PA Expressivo Registro de uma Paleolaguna do Cenozóico Brasileiro. In: Winge,M.;Schobbenhaus,C.; Berbert-Born,M.; Queiroz,E.T.; Campos,D.A.; Souza,C.R.G.;Fernandes,A.C.S.. (Org.). Sítios Geológicos e Paleontológicos do Brasil. Brasília. 2: 34-41.

Távora, V.A., Fernandes, J., 1999. Estudo de los foraminiferos de la Formación Pirabas (Mioceno Inferior), Estado do Pará, Brasil, y su correlación com faunas del Caribe. Revista Geológica de América Central, 22: 59-70.

Távora, V.A., 1994a. Bythocytheridae, Cytherideidae e Cytheruridae (CrustáceaOstracoda) na Formação Pirabas (Eomioceno) - Estado do Pará. Boletim do Museu Paraense Emílio Goeldi, Série Ciências da Terra, Rio de Janeiro, 6: 91-113.

Távora, V.A., 1994b. Hemicytheridae, Loxoconchidae, Paradoxostomatidae, Pectocytheridae e Trachyleberidadae (Crustácea-Ostracoda) na Formação Pirabas (Eomioceno) - estado do Pará. Boletim do Museu Paraense Emílio Goeldi, Série Ciências da Terra, Rio de Janeiro, 6: 115-140.

Távora, V.A., 1994c. Ostracodes da formação Pirabas (Mioceno Inferior) no Estado do Pará. Acta Geológica Leopoldensia, São Leopoldo, v. 17, n.39/1, p. 119-129.

Távora, V.A., Silveira, E.S.F., Milhomem Neto, J.M., 2007. Mina B-17, Capanema, PA - Expressivo Registro de uma Paleolaguna do Cenozóico Brasileiro. In: Winge,M.; 
Schobbenhaus,C.; Berbert-Born,M.; Queiroz,E.T.; Campos,D.A.; Souza,C.R.G. ; Fernandes,A.C.S. (Edit.) Geological and Palaeontological Sites of Brazil.

Teeter, J.W., 1995. Holocene saline lake history, San Salvador Island, Bahamas in Curran, H.A., and White, B., eds., Terrestrial and Shallow Marine Geology of the Bahamas and Bermuda: Geological Society of America Special Papers, v. 300, p. 117-124.

Uliana, M.A., Musacchio, E.A., 1978. Microfossiles calcáreos no-marinos del Cretacico superior en Zampal, Provincia de Mendoza, Argentina. Ameghiniana, Buenos Aires, tomo $15, \mathrm{n}^{\circ} 1-2$, p. 111-135.

Viviers, M.C, Koutsoukos, E.A, Silva-Telles JR., A.C., Bengtson, P., 2000. Stratigraphy and biogeographic affinities of the late Aptian-Campanian ostracods of the Potiguar and Sergipe basins in northeastern Brazil. Cretaceous Research, 21:407-455.

Whatley, R.C., Watson, K., 1988. A preliminary account of the distribution of ostracoda in recent reef and reef associated environments in the Pulau Serbu or Thausand Island Group, Java Sea. T. Hanai, N. Ikeya, K. Ishizaki (Eds.), Evolutionary Biology of Ostracoda: Its Fundamentals and Applications, Elsevier/Kodansha, AmsterdamTokyo (1988), pp. 399-411.

Whatley, R. C., Toy, N., Moguilevsky, A. and Coxill, D., 1995. Ostracoda from the South West Atlantic Part 1. The Falkland Islands. Revista Espanõla de Micropaleontologia 27, 17 - 38.

Wouters, K., Martens, K., 1992. Contribution to the knowledgeof the tanganyikan cytheraceans, with the description of Mesocyprideis nom. nov. (Crustacea, Ostracoda). Bulletin Koninlikkijk Belgisch Instituut voor Natuurwetenschappen, Biologie, 62:159-166.

Wouters, K., Martens, K., 1994. Contribution to the knowledge of the Cyprideis species flock (Crustacea, Ostracoda) of Lake Tanganyika, with the description of three new species. Bulletin Koninlikkijk Belgisch Instituut voor Natuurwetenschappen, Biologie, 64:111-128.

Zabert, L.L., 1978. Micropaleontología de la Formación Parana (Mioceno superior) em él subsuelo de la Provincia de Santa Fé, Republica Argentina. Facena, 2:101-165.

\section{FIGURE CAPTIONS}

Figure 1. Location of the studied areas from northern Equatorial margin of Brazil (Google Earth, 2014). 
Figure 2. Geological and stratigraphic settings of northeast from Pará State: (A) distribution of neogene deposits (grey color) and basement units of Gurupi Belt (dott texture) with indications of studied localities; (B) overview of the B-17 quarry in the Pirabas Formation; (C) B-17 quarry composite section with the location of samples; (D) drill core FPR-160 Primavera composite section with the location of samples for paleontological (ostracods) analyses; and (E) sample of shale with fine laminations from drill core FPR-160 Primavera.

Figure 3. Scale bar: $100 \mu \mathrm{m}$ : C: carapace; LV: left valve; RV: Right Valve. Figs. 1-8. Perissocytheridea punctoreticulata n. sp.: Fig. 1. Male, C, LV, external view, MPEG515-M. Fig. 2. Male, C, RV, external view, MPEG-515-M. Fig. 3. Dorsal view, MPEG515-M .Fig. 4. Female, C, LV, external view, MPEG-516-M. Fig. 5. Female, C, RV, external view, MPEG-516-M. Fig. 6. Female, RV, external view, MPEG-517-M. Fig. 7. Female, LV, external view, MPEG-518-M. Fig. 8. Detail of the muscle scars, RV, MPEG-518-M. Figs. 9-17. Perissocytheridea largulateralis n. sp.: Fig. 9. Female, C, LV, external view, MPEG-519-M. Fig. 10. Female, C, RV, external view, MPEG-519M. Fig. 11. LV, internal view, MPEG-521-M. Fig. 12. Male, C, LV, external view, MPEG-508-M. Fig. 13. Male, C, RV, external view, MPEG-520-M. Fig. 14. Female, Dorsal view, MPEG-519-M. Fig. 15. Male, Dorsal view, MPEG-520-M. Figs. 16. Male, RV, external view, MPEG-522-M. 17. RV, internal view, MPEG-522-M.

Figure 4. Scale bar: $100 \mu \mathrm{m}$ : C: carapace; LV: left valve; RV: Right Valve. Figs.1-6. Perissocytheridea colini n. sp.: Fig. 1. Female, C, LV, external view, MPEG-523-M. Fig. 2. C, RV, external view, MPEG-523-M. Fig. 3. Female, Dorsal view, MPEG-524M. Fig. 4. Male, C, LV, external view, MPEG-525-M. Fig. 5. Male, C, RV, external view, MPEG-525-M. Fig. 6. Male, LV, internal view, MPEG-526-M. Figs.7-17. Perissocytheridea pirabensis n. sp. Fig. 7. Male, LV, external view, MPEG-530-M. Fig. 8. RV, external view, MPEG-530-M. Fig. 9. Dorsal view, MPEG-530-M. Fig. 10. Female, LV, external view, MPEG-527-M. Fig. 11. Female, RV, external view, MPEG527-M. Fig. 12. RV, internal view, MPEG-530-M. Fig. 13. Male, LV, external view, MPEG-529-M. Fig. 14. Male, RV, external view, MPEG-529-M. Fig. 15. Female, LV, external view, MPEG-531-M. Fig. 16. Female, RV, external view, MPEG-531-M. Fig. 17. Dorsal view, MPEG-531-M. 
Figure 5. Scale bar: $100 \mu \mathrm{m}$ : C: carapace; LV: left valve; RV: Right Valve. Figs. 1 - 5. Perissocytheridea pirabensis n. sp.: Fig. 1. Female, C, LV, external view, MPEG-532M. Fig. 2. Female, C, RV, external view, MPEG-532-M. Fig. 3. Juvenile, Dorsal view, MPEG-532-M. Fig. 4. Juvenile, Male, C, LV, external view, MPEG-533-M. Fig. 5. Juvenile, Male, C, RV, external view, MPEG-533-M. Figs. 6 -14. Perissocytheridea aff. P. pumila: Fig. 6. Male, Dorsal view, MPEG-535-M. Fig. 7. Female, C, LV, external view, MPEG-534-M. Fig. 8. Female, C, RV, external view, MPEG-534-M. Fig. 9. Female, Dorsal view, MPEG-534-M. Fig. 10. Male, C, LV, external view, MPEG-535-M. Fig. 11. Male, C, RV, external view, MPEG-535-M. Fig. 12. Detail of the muscle scars, RV, MPEG-534-M. Fig. 13. Female, RV, internal view, MPEG-534M. Fig. 14. Detail of the hinge, RV, MPEG-534-M. Figs. 15 - 17. Perissocytheridea aff. P. brachyforma subsp. excavata Fig. 15. Female, C, LV, external view, MPEG539-M. Fig. 16. C, RV, external view, MPEG-539-M. Fig. 17. Dorsal view, MPEG539-M.

Figure 6. Scale bar: $100 \mu \mathrm{m}$ : C: carapace; LV: left valve; RV: Right Valve. Figs. 1-3. Perissocytheridea aff. P. brachyforma subsp. excavata: Fig. 1. Male, RV, internal view, MPEG-540-M. Fig. 2. Female, LV; internal view, MPEG-540-M. Fig. 3. LV, internal view, MPEG-540-M. Figs. 4 - 6. Perissocytheridea sp. 1: Fig. 4. C, LV, external view, MPEG-542-M. Fig. 5. C, RV, external view, MPEG-542-M. Fig. 6. Dorsal view, MPEG-542-M. Figs. 7 - 9. Perissocytheridea sp. 2: Fig. 7. C, LV, external view, MPEG-543-M. Fig. 8. C, RV, external view, MPEG-543-M. Fig. 9. Dorsal view, MPEG-543-M. Figs. 10 - 12. Perissocytheridea sp. 3: Fig. 10. LV, external view, MPEG-544-M. Fig. 11. RV, external view, MPEG-545-M. Fig. 12. LV, internal view, MPEG-544-M. Figs. 13 - 15. Perissocytheridea sp. 4: Fig. 13. Female, RV, external view, MPEG-546-M. Fig. 14. Female, RV, internal view, MPEG-546-M, Fig. 15. Male, RV, external view, MPEG-547-M. Figs. 16 - 18. Perissocytheridea sp. 5: Fig. 16. LV, external view, MPEG-548-M. Fig. 17. RV, external view, MPEG-548M. Fig. 18. Dorsal view, MPEG-548-M.

Figure 7. Scale bar: $100 \mu \mathrm{m}$ : SEM photomicrographs of three Ammonia species and two Elphidium species representative of the environments recorded in the samples: Figs. 1-3. Ammonia parkisoniana, side view. Figs. 4-6. Ammonia sp., side view. Figs. 
7-8. Ammonia beccari, side view. Figs. 9-11. Elphidium sp, side view. Figs. 12-14. Elphidium (Criboelphidium) poyanum, side view.

Figure 8. Abundance of Perissocytheridea species, Ammonia and Elphidium genera along the studied sections.

Figure 9. Distribution of Perissocytheridea species along the geological time according with global records.

Fig. 10. Abundance of the genera ostracods and foraminifera associations in the Pirabas localities: Graphs of (A) to (E) shows the genera distribution between Ammonia and Elphidium foraminifera and ostracods from Mine B-17: (A) and (B) Haplocytheridea and Cytheridea data realized by Nogueira et al. (2011), respectively; (C) Distribution of genus Perissocytheridea; (C) and (D) Distribution of genera Ammonia and Elphidium, respectively. Graphs of (F) to (J) shows the genera distribution between Ammonia and Elphidium foraminifera and ostracods of the FPR-160 core in Primavera location. Horizontal axis: number of each genera; vertical axis: depth and samples collected.

\section{TABLES}

Table 1. Frequency of the genus Perissocytheridea along the main samples from the two localities in the present study.

Table 2. Geographic distribution of the more typical mixohaline species in Recent sediments.

Table 3. Significant correlations between biological and environmental factors (Salinities, conductivity, temperatures and substrates) in Recent sediments. 


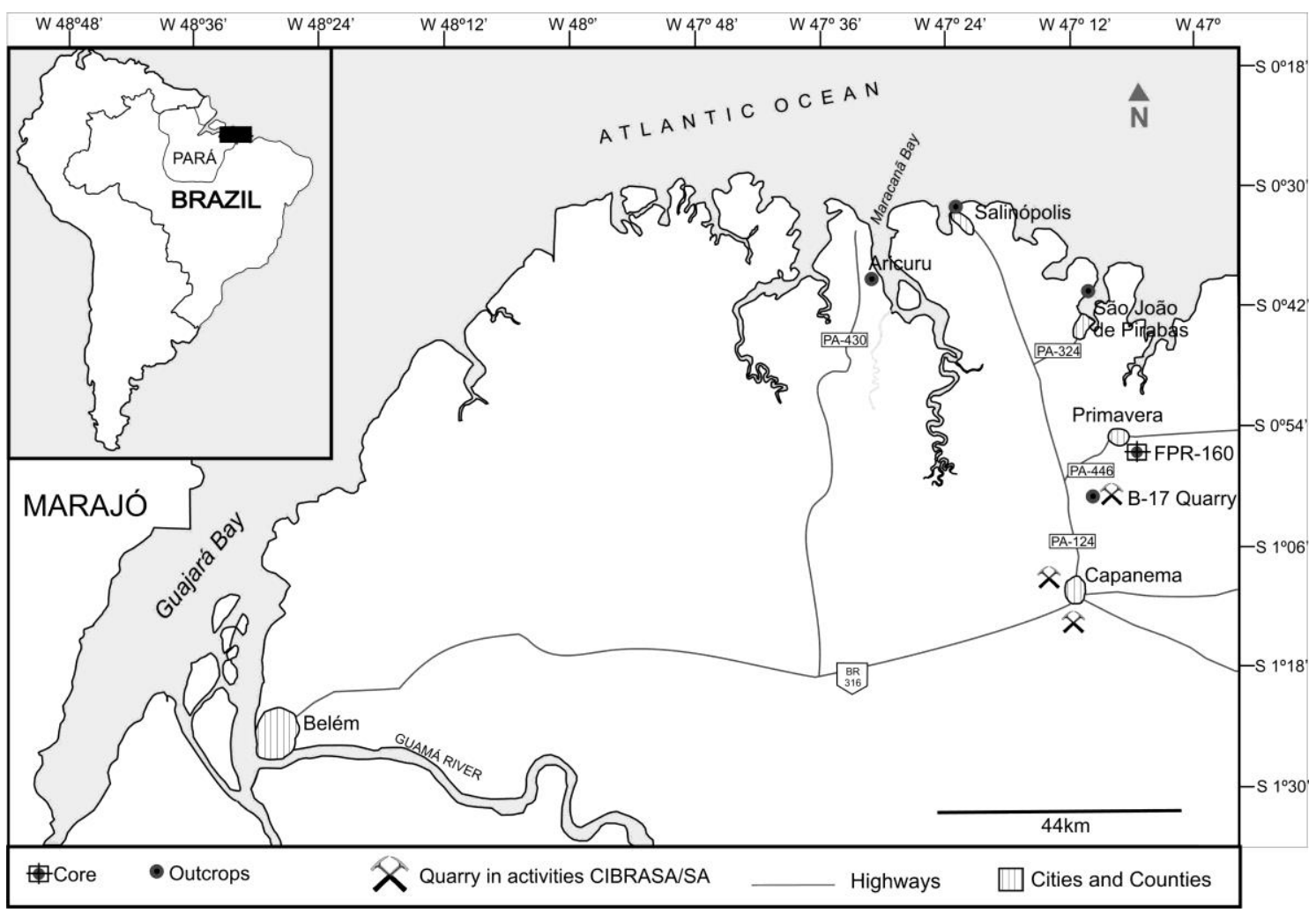




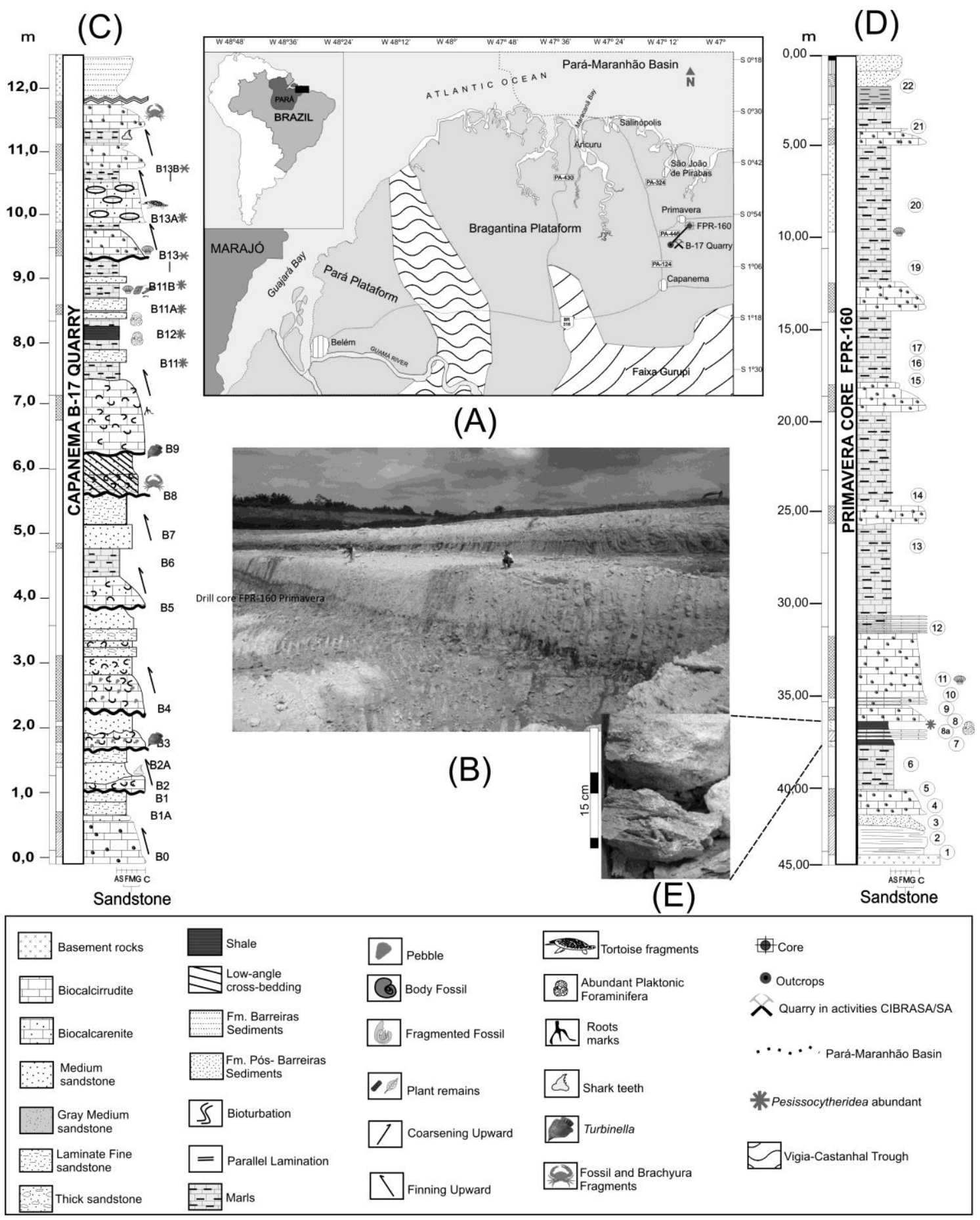




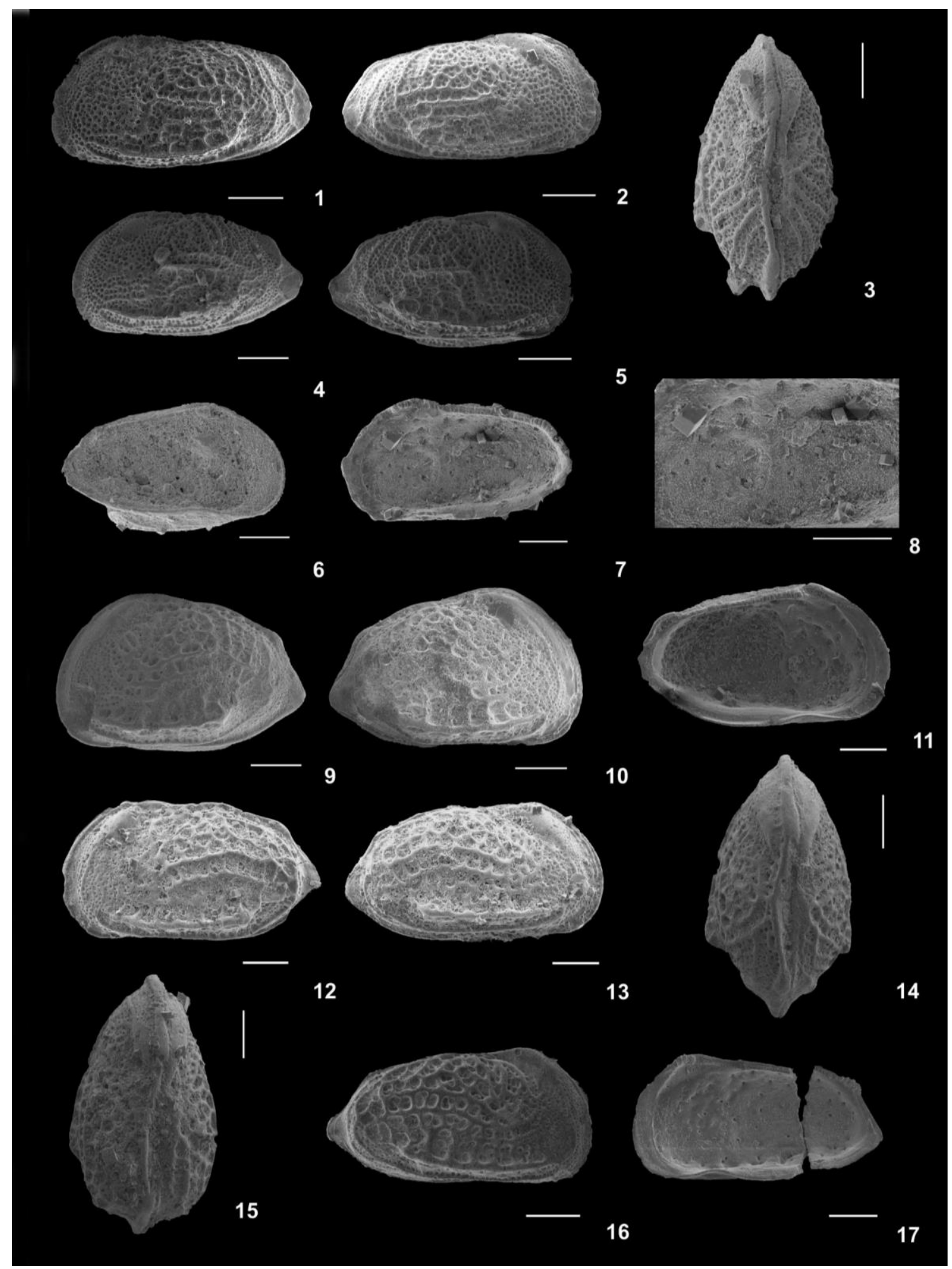




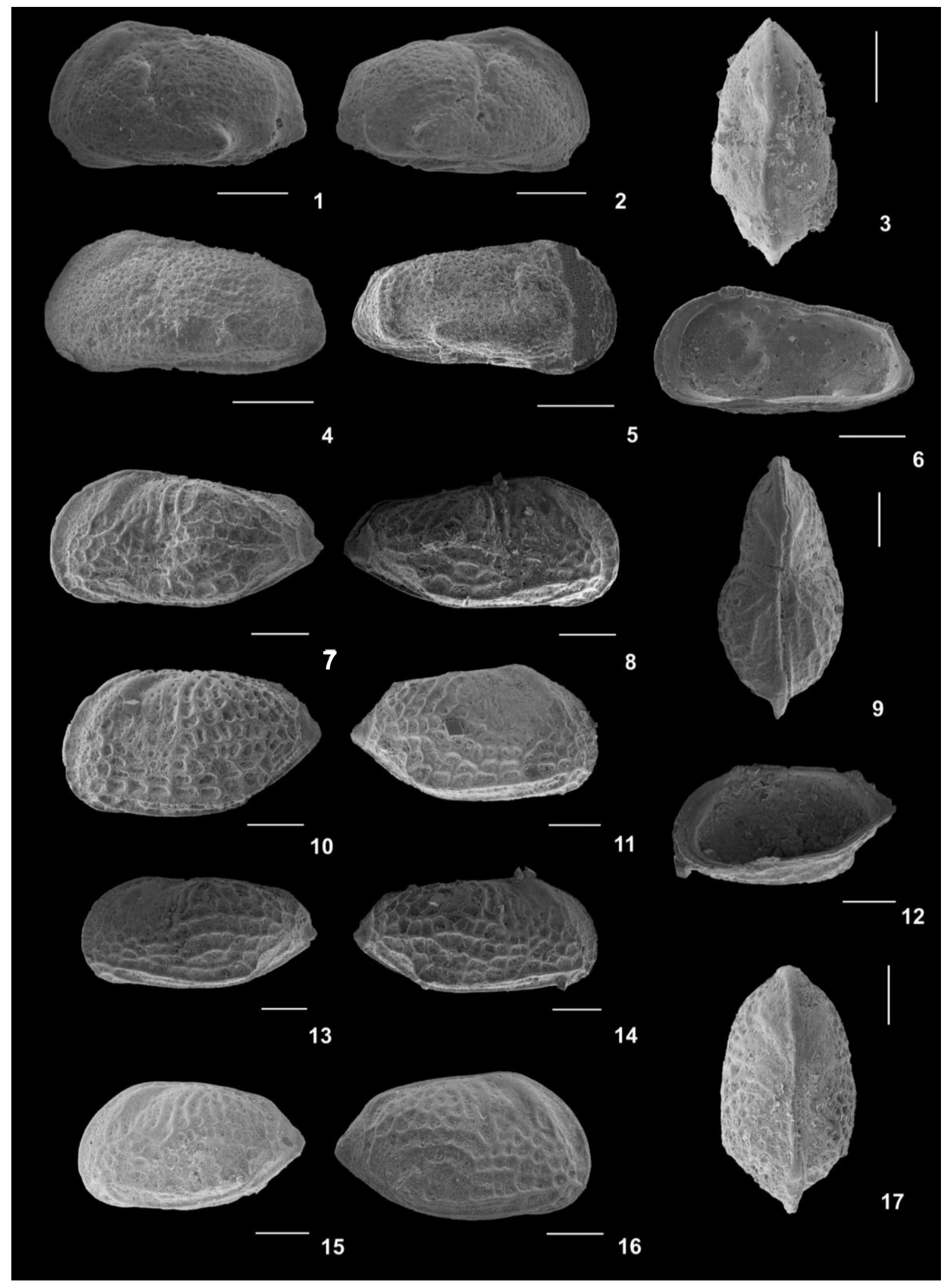




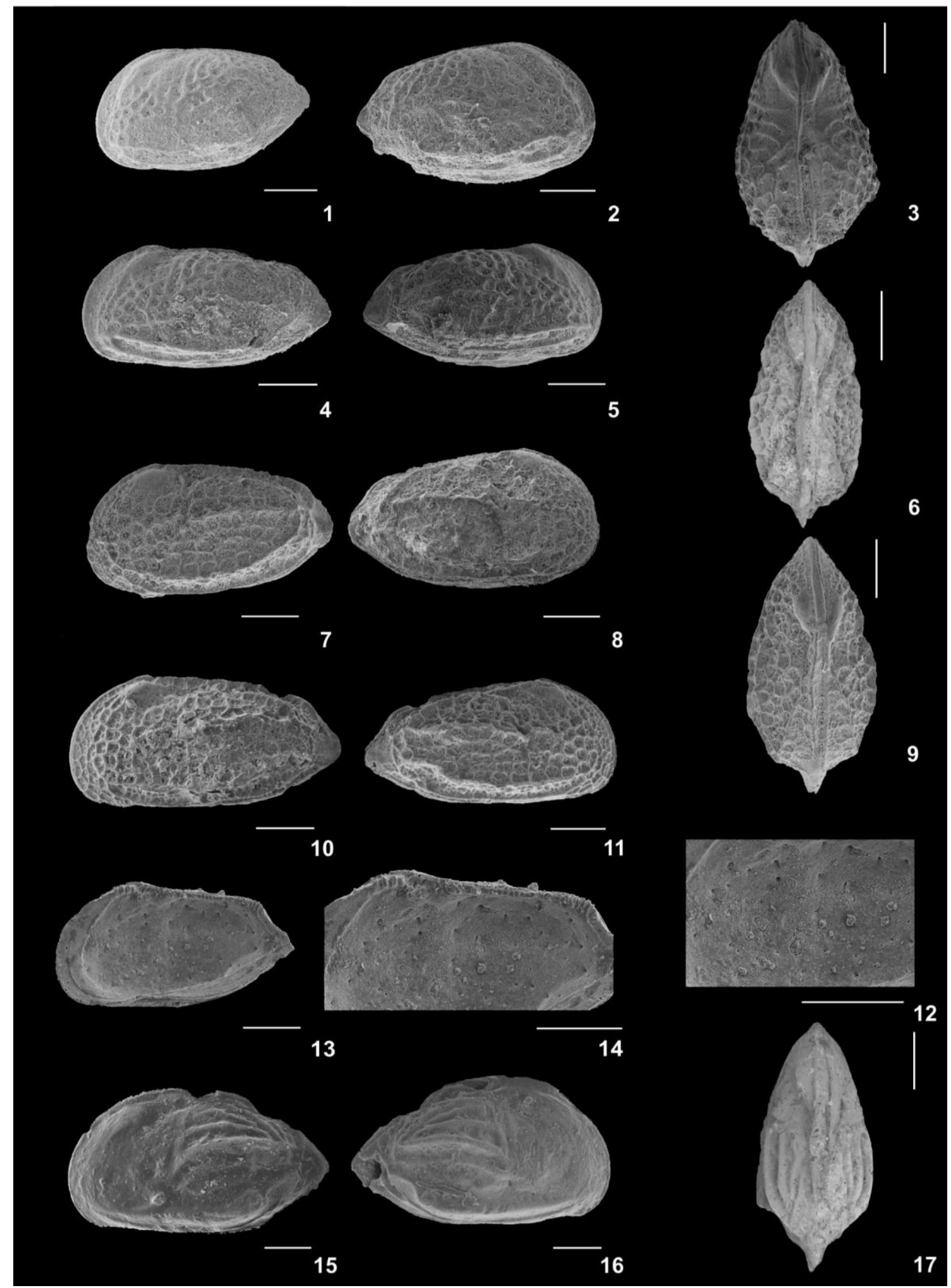




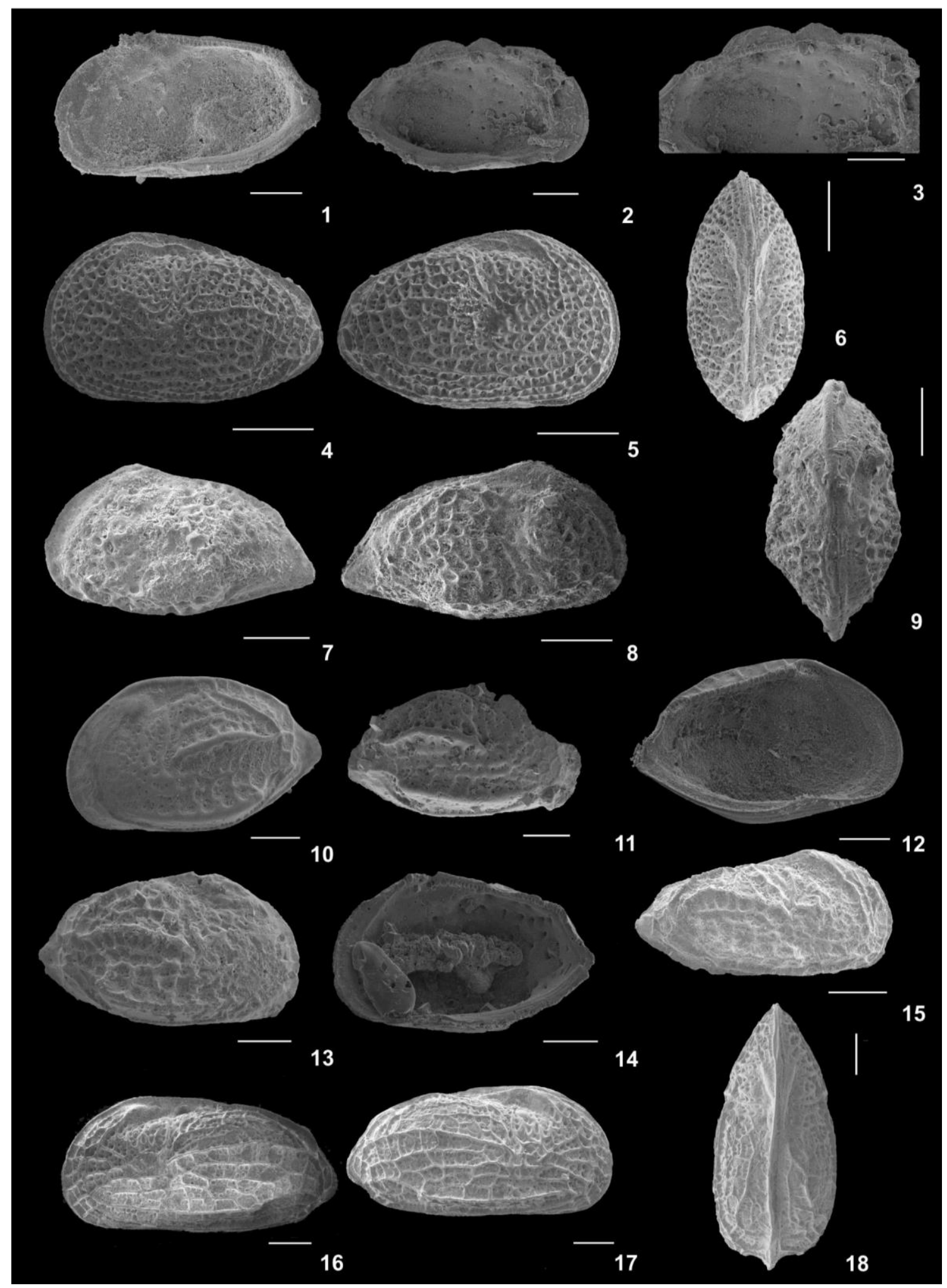




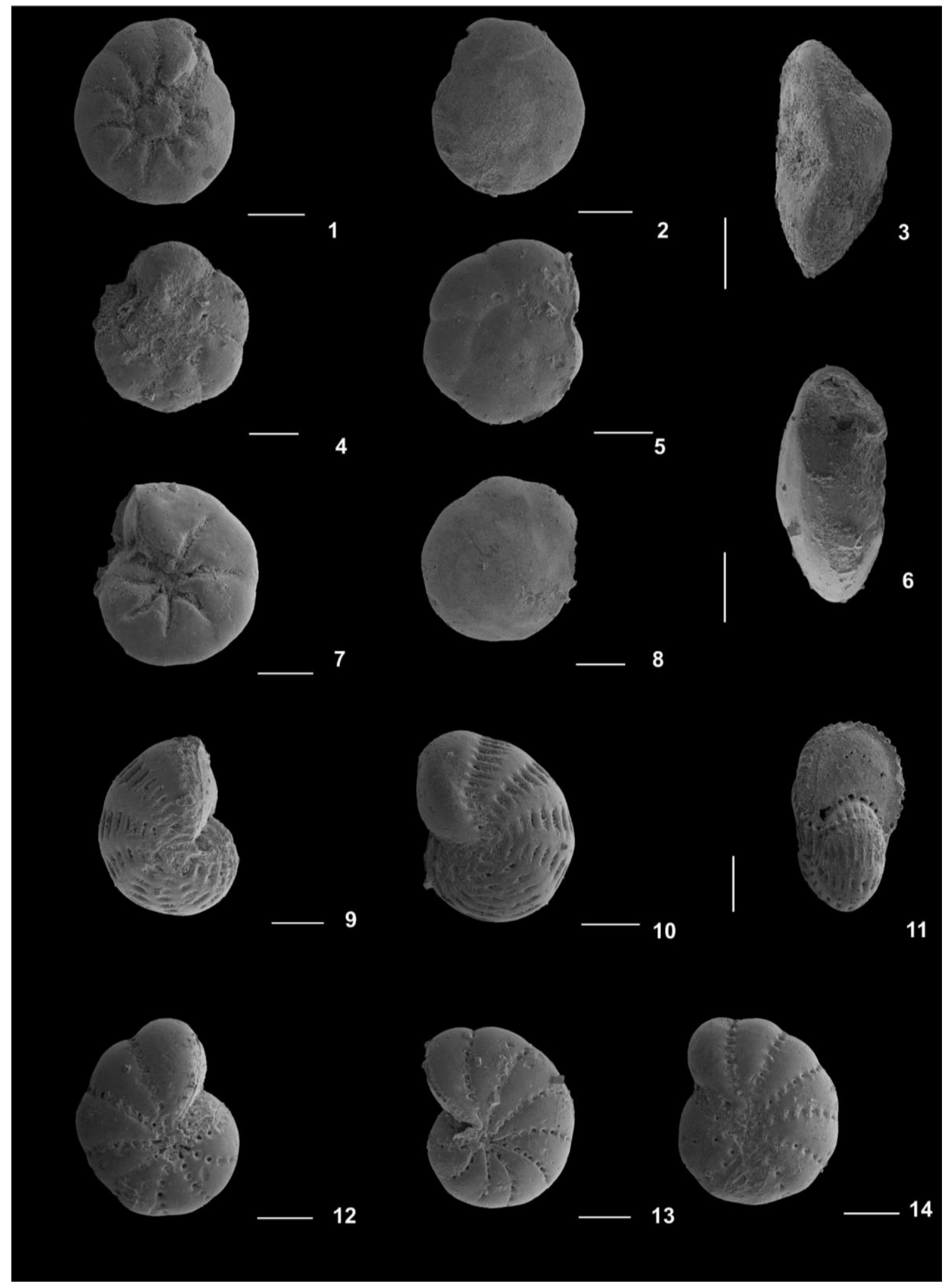




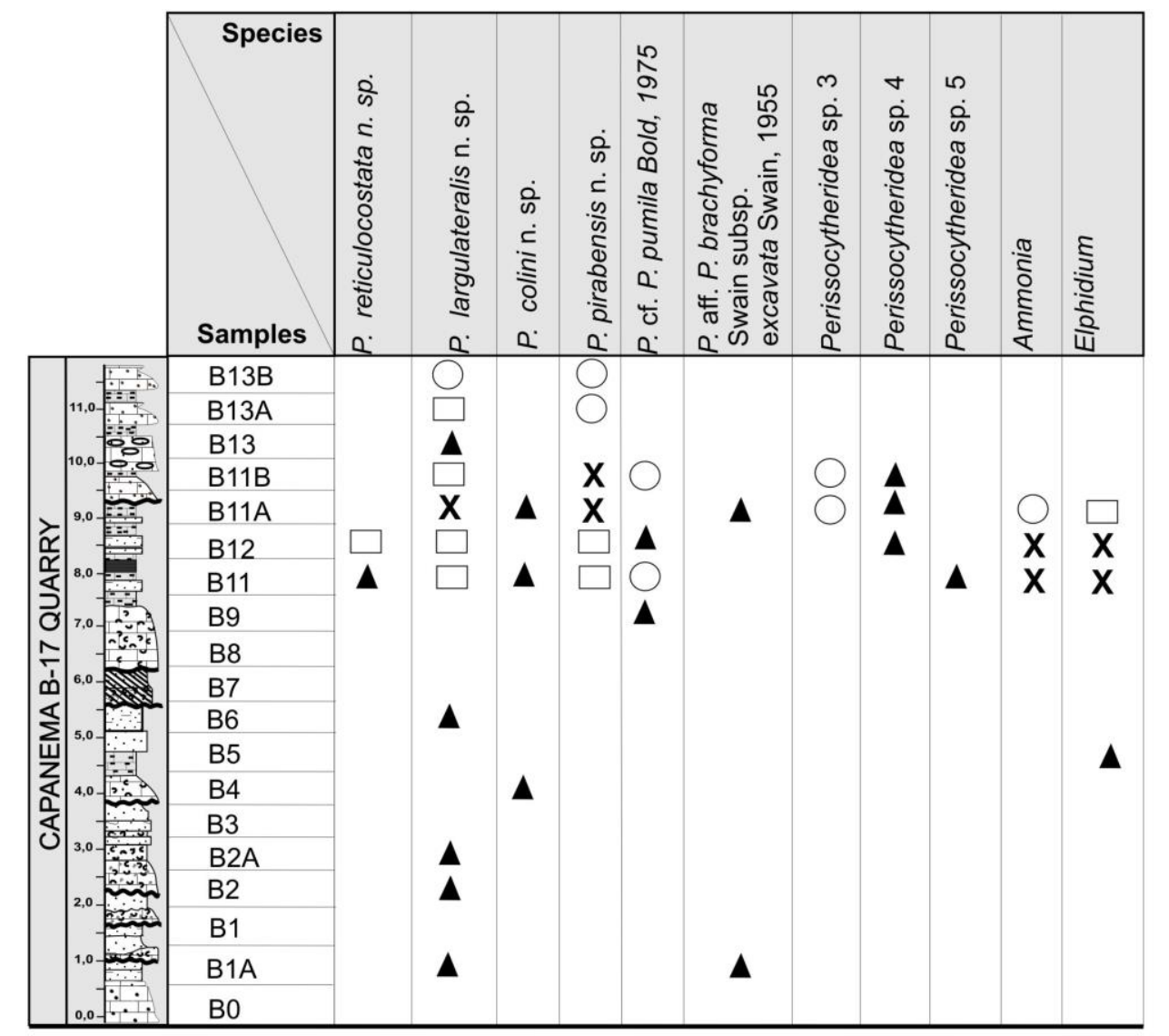

X Abundant ( $>15$ specimens)

$\square$ Common (>6 and $<15$ specimens)

Rare ( $>2$ and $<6$ specimens)

$\Delta$ Present (1 or 2 specimens)

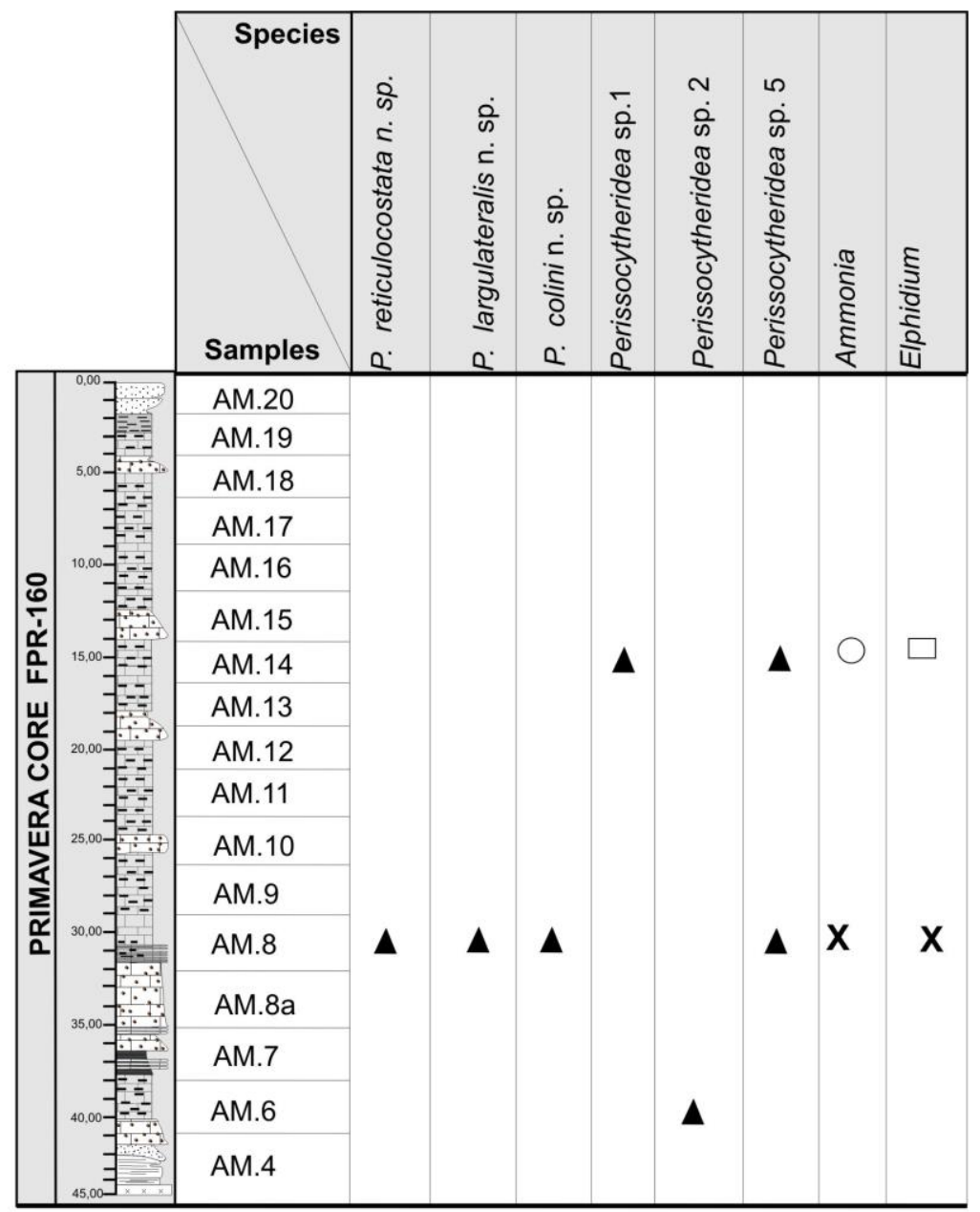




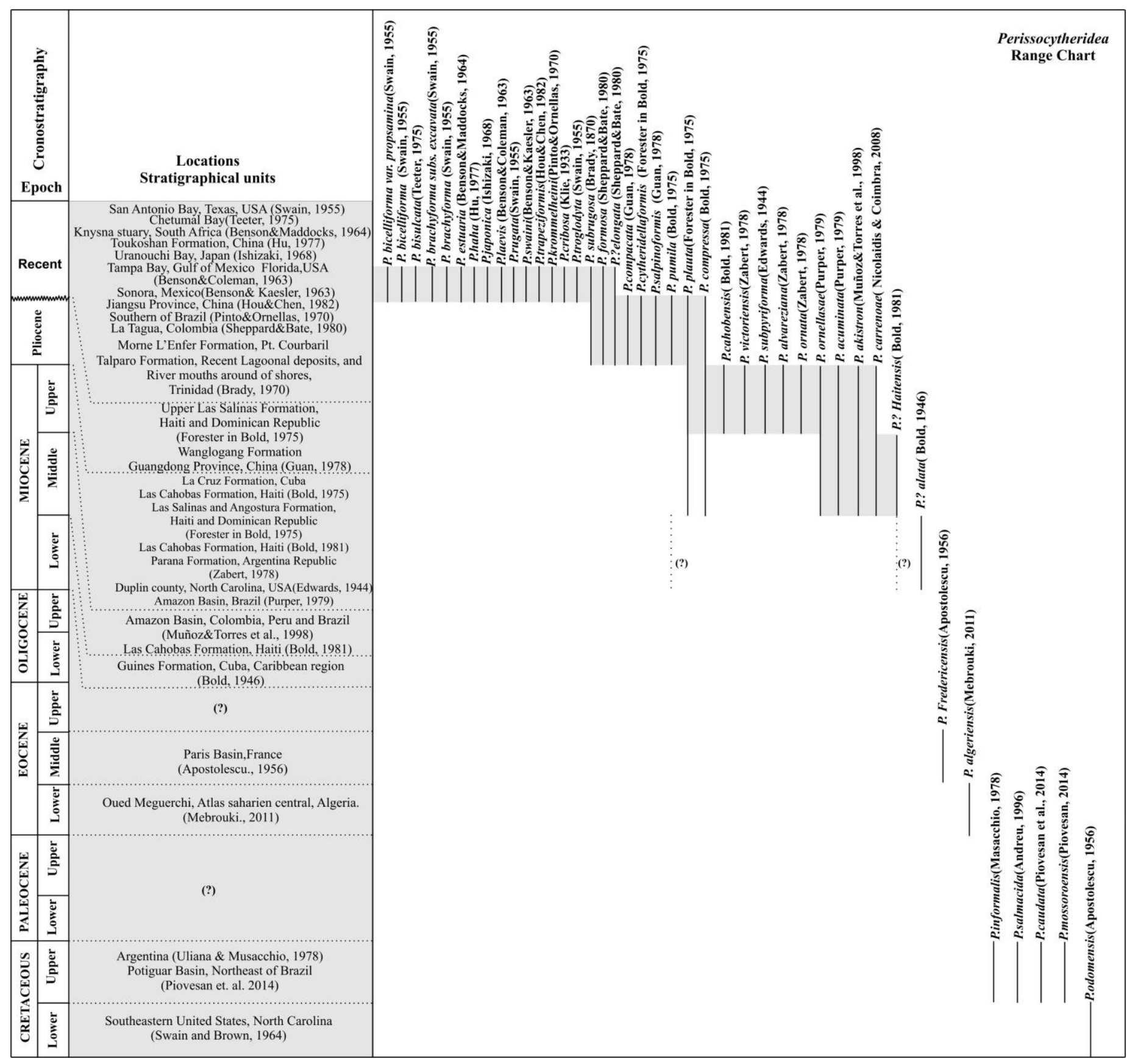


B-17 Quarry

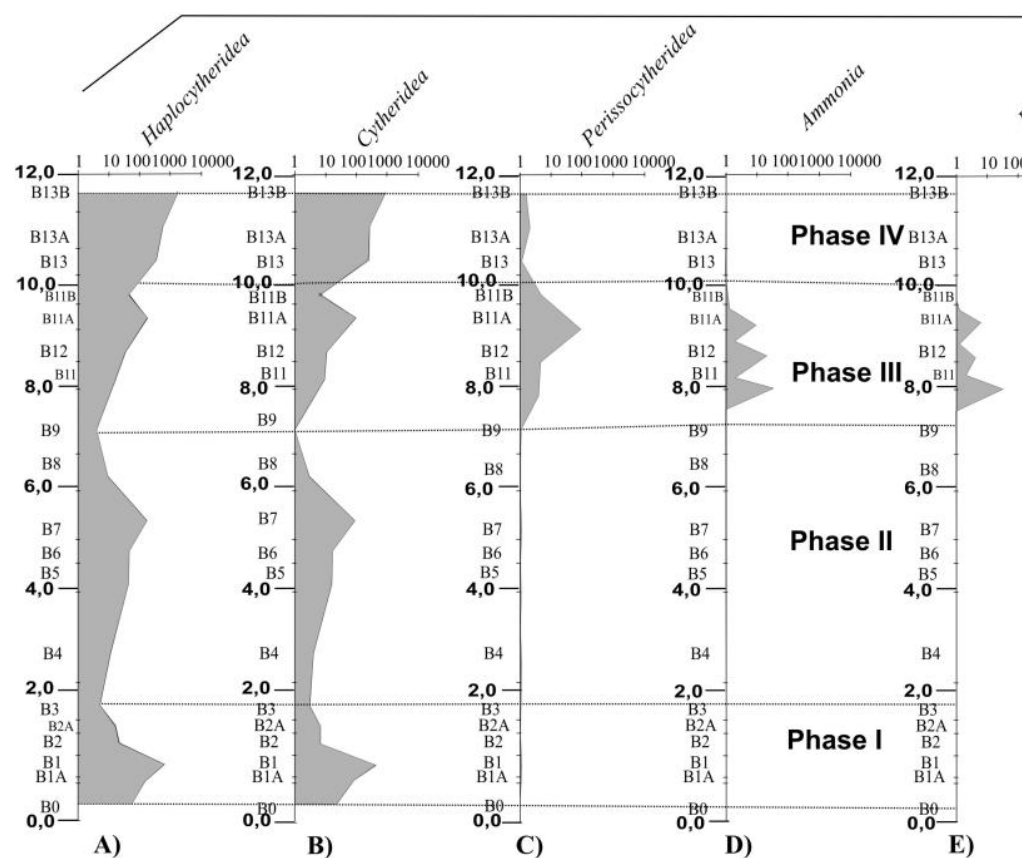

Drill core Primavera FPR-160

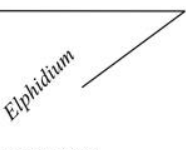

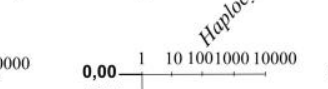

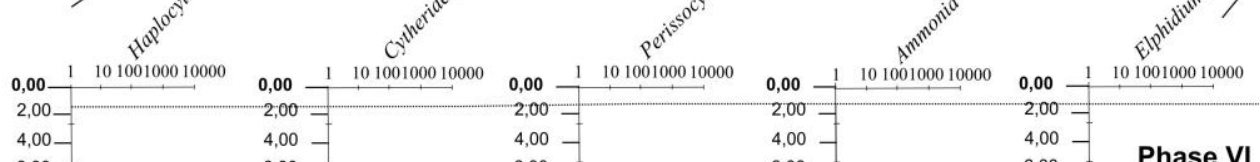

$6,00-$

6,00
AM 20,000

$10,00-10$
AM. 110,00

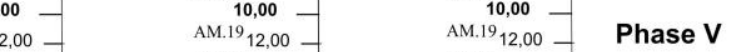

AM.17 14, 14,00-

AM. $1912,00-$

AM. $192,00-\quad$ AM. $1912,00-$

AM.18 1400

Phase VI

AM.

\begin{tabular}{lll}
$16,00-1$ & AM. 17 & 16,00 \\
$18,00-16$ & AM. 15 & 18,00 \\
\hline & & 20,00
\end{tabular}

$\begin{array}{rr}20,00 \\ 22,00\end{array} \quad 20,00$

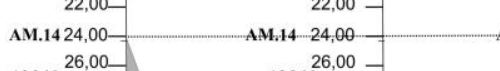

AM. 13 26,00- $\quad$ AM. $13,26,00$

30,00

30,00

$\begin{array}{ll}\text { AM. } 17 & 16,00 \\ \text { AM.16 } & 16,00 \\ \text { AM. } 15 & 18,00\end{array}$

AM. $176 \quad 16,00-$

AM.17 $17.14,00-$

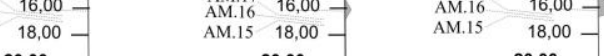

$\begin{array}{ccc}20,00 & 20,00 & 20,00 \\ 22,00 & 22,00 & 22,00\end{array}$

Phase IV$$
\text { AM. } 12,02,00
$$

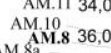

AM. 38,00
AM. 40,00
AM. 401,00

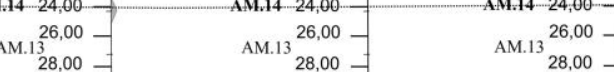

$22,00-$

$24,00-\quad$ AM.14 24,00

$26,00-$

AM. $441,00=$
$43,00-$
$45,00-$

AM.11.34,00
AM.10.
AM. 836,00

AM. $12,32,00$

30,00

30,00
AM. $12,32,00-$

Phase III

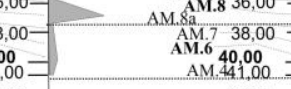

AM.10. 34,00

AM.7 38,00
AM.6
AM 400

43,00
45,00

F)

43,00
45,00

H)

AM.11 34,00

AM. A AM. 836,00

AM.110 34,00

Phase II

AM. ${ }^{A} \cdot 38,00=$ Phase I

43,00

43,00
45,00 


\begin{tabular}{|c|c|c|c|}
\hline Localities & $\begin{array}{c}\text { Depth } \\
\text { (m) }\end{array}$ & Samples & $\begin{array}{c}\text { Frequency } \\
(\%)\end{array}$ \\
\hline \multirow{10}{*}{$\begin{array}{l}\vec{\Xi} \\
\stackrel{\vec{Z}}{\Xi} \\
\vec{D} \\
\dot{n}\end{array}$} & \multirow{10}{*}{$\sim 14$} & $\overline{\mathrm{B} 11 \mathrm{~B}}$ & 21 \\
\hline & & B11A & 31 \\
\hline & & B12 & 14 \\
\hline & & B11 & 12 \\
\hline & & B9 & 1 \\
\hline & & B6 & 1 \\
\hline & & B4 & 1 \\
\hline & & $\mathrm{B} 2 \mathrm{~A}$ & 2 \\
\hline & & B2 & 1 \\
\hline & & B1A & 2 \\
\hline 8 & $\sim 24$ & AM. 14 & 13 \\
\hline$\frac{\alpha}{2}$ & $\sim 36$ & AM. 8 & 67 \\
\hline ن & $\sim 38$ & AM. 6 & 20 \\
\hline
\end{tabular}


preferences associated species Mixohaline waters

\begin{tabular}{ll}
\hline Sepetiba Bay & Drazil) \\
(Southeastern of Brá & Tramandaí Lagoons \\
(Southeastern of Brazil) & P
\end{tabular}

Copano Bay, Laguna Madre, and Redfish Bay (Texas, North America,

USA)

$$
\text { Florida }
$$

Dias-Brito et al. (1988)

Coimbra et al. (1994)

Pinto and Ornellas (1970)

Ornellas (1974)

(Southwestern, USA)

Texas, North America, (USA)

King and Kornicker (1970)

Lagoon

P. Kroemmelbeini

Lagoon system

P. Kroemmelbeini Mynicythere heinii

P. brachyforma

P. brachyforma excavata

$$
P \text {. rugata }
$$

P. swaini

Keyser (1977)

Coastal system

P. brachyforma

$$
\text { P. cribrosa }
$$

$P$. brachyforma, $P$.

Garbett and Maddocks

(1979)

Bays

bicelliforma, P. excavata $P$. rugata, $P$. troglodyta

Cananéia/ Iguape

Coimbra et al. (2007)

(Southeastern of Brazil)

Lago Petén Itza

(Guatemala)

\section{P. Kroemmelbeini}

Estuary

Whatleyella sanguinettiae

Cyprideis multidentada

Cyprideis multidentada

Cyprideis salebrosa hartmanni
Cyprideis torosa

Cyprideis bensoni

Cyprideis species

Cypridopsis vidua

Heterocypris punctata,

Cyprideis beaveni,

Cypria pseudocrenulata Tanella sp.

Cyprideis salebrosa

Whatleyella sanguinettiae

Cyprideis multidentada

Minicythere heinii

Tanella gracilis

Thalassocypria sp., Cypridopsis okeechobei, Darwinula stevensoni, Limnocythere opesta, Heterocypris punctata, $P$. globula, Pseudocandona sp., Strandesia intrépida, Candonocypris

serratomarginata, C. ilosvayi, $C$. brevisaepta?, Stenocypris. major 


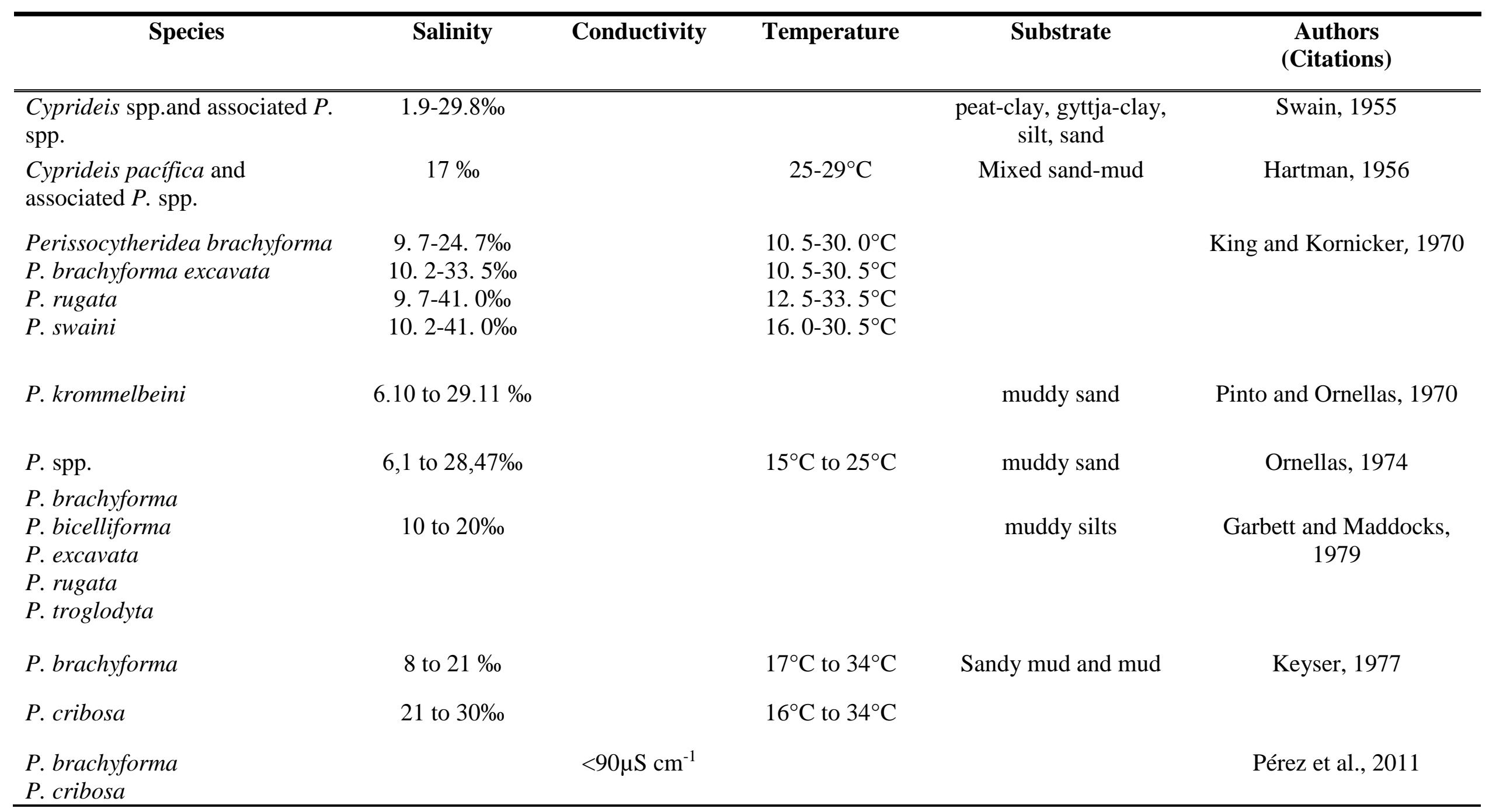


